$$
\begin{gathered}
\mathbf{s} \\
534 \\
\mathrm{M} 4 \mathrm{As}
\end{gathered}
$$


on

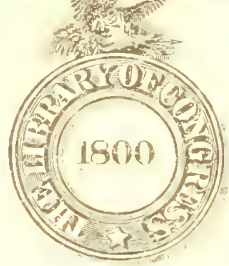

Olass $J^{2}: t$

Book i L L L 



$$
\text { , }
$$ 


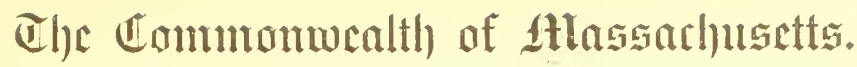

\author{
R E P O R T
}

OF THE

\title{
BOARD OF EDUCATION
}

OF

\author{
MASSACHUSETTS
}

ON

\section{Agricultural Education.}

\begin{abstract}
Submitted to the Legislature of Massachusetts in Accordance with Resolves approved

May 28 and June 10, 1910.
\end{abstract}

$$
\text { Januari, } 1911 .
$$

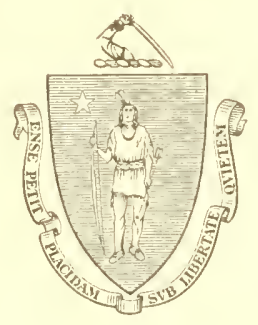

BOSTON:

WRIGHT \& POTTER PRINTING CO., STATE PRINTERS, 18 Post Office Square. 1911. 



\section{CONTENTS.}

Submission of the Report to the Legislature,

PAGE

I. - Preliminary Statements, Summary of the Report and Recommendations,

II. - Does Massachusetts Farming warrant the Establishment of a System of Agricultural Schools? . . . . . . 12

III. - The System of Agricultural Schools recommended for Massachusetts, . . . . . . . . . . . . 2

IV. - Co-operation between sehool and Home Farm Necessary to an Effective System of Agricultural Schools for Massachusetts, .

V. - The Part-time and Project Method Necessary to an Effective System of Agricultural Schools for Massachusetts,

VI. - The Problem of securing Competent Instructors for a System of Agricultural Sehools in Massachusetts,

VII. - Agricultural Departments in Public High Schools the Principal Present Need in Massachusetts Agricultural Education, . . 66

VIII. - Possible Locations for Agricultural Schools or Departments,

IX. - Recommendation with regard to Agricultural Education for Worcester, . . . . . . . . . . . d . d

X. - Agriculture as a Phase of Liberal Education in the High Schools of Massachusetts,

XI. - Agriculture as a Phase of Lilseral Education in the Elementary Schools of Massachusctts,

\section{APpendix.}

Proposed Codifieation of the Law relating to Industrial, Agricultural and Household Arts Education, 



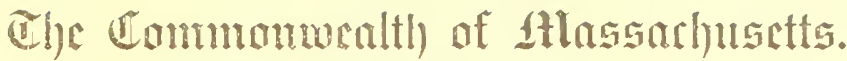

\author{
REPORT ON \\ AGRICULTURAL EDCCATION.
}

To the Honorabie the senate and House of Representatives.

In accordance with the provisions of chapters 108 and 133 , Resolves of 1910 , concerning the advisability of establishing a srstem of agricultural schools throughont the Commonwealth, and concerning the practicability and desirability of establishing a farm school in the city of Worcester, the Board of Education herewith reports the results of investigations and recommendations, made mider its direction by the Commissioner of Education, David Snedden, Deputy Commissioner Charles 1. Prosser and Special Agent Rufus WV. Stimson.

The Board adopts the report and endorses the recommendations.

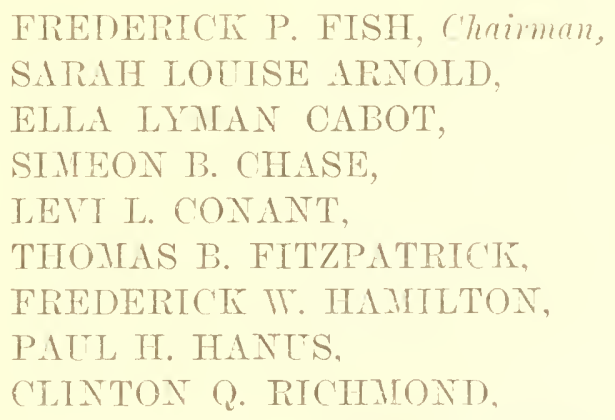

FREDERICI P. FISH, Chamman, SARAH LOTISE ARNOLD, ELLA LIMAN CABOT, SIMEON B. CHASE, I.EYT L. CONANT, TIIONAS B. FITZPATRICI, FREDERTCK IT. HAMILTON, PALL H. HANES, CINTTON R. RTCHMOND. Members of the Board.

$\mathrm{J}_{A N}, 1,1911$. 



\section{PRELIMINARY STATEMENTS, SUMMARY OF THE REPORT} AND RECONMENDATIONS.

Following is the text of the resulves passed by the Legislat ture:-

\section{Resolves of 1910, Chapter 108.}

Resolece, That the state board of elucation shall investigate the practicability and desirability of establishing a farm school in the eity of Worcester in which instruction may be given, free, in the raising of fruits, regetables, flowers, grains, plants and trees, and in the care of domestic animals, and in which similar instruction suitable to their years may be given to children. The board shall report in print to the general cont, with snch recommendations as it may deem proper, not later than Jannary fifth, nineteen hmolres and eleven. [1pproved May $29,1910$.

\section{Resolves of 1910, Chapter 133.}

Resolved, That the board of eduration is hereby anthorized and directed to investigate the advisability of establishing a system of agrienltural schools throughout the conmonwealth, and to report the result of its investigation with its recommentations to the next general cont not later than the second Wednesday in Jamnary, nineteen hmured and eleven. [Approved June 10, 1910.

In obedience to these resolves, the Board of Education directed the Commiswioner of Education to make the necessary investigations and to engage expert assistance. Mr. Rufus W. Stimson, director of Smith's Agrimultural Sehool and Northampton School of Industrics, was appointed to assist in making the investigations and preparing the report.

Special acknowlerlomont is here marle of the assistance of the following: President Kenvon L. Butterfield and membeis of the faculty of Masalunsetts Igrientural college; Scere tary J. Lewis Ellsworth of the State Board of Agriculture; Mr. Dick J. Croshy, spereialist, and Mr. F. Wr. IIowe, assistant specialist, in agrioultural education, of the Cniter States Department of Agriemlture. ()ffice of Experiment Stations; Mr. 
Arthur C. Monahan, agricultural specialist of the United States Bureau of Education; the Hon. C. D. Richardson, Past Master, and the Hon. Charles M. Gardner, Master, of the Massachusetts State Grange; and many other eitizens of Massachusetts.

A brief survey has been made of the development of agricultural education in Massachusetts and like work elsewhere. The economic status and prospects of farming, as conducted by both men and women, in this State, have been examined.

Selected and typical centers have been studied, as to the facilities for transportation, as to the most promising lines of farming in practice, and as to the probable enrollment in an agrieultural school or department. All parts of the State have thus receired attention, with the exception of the islands of Dukes and Nantucket. It will be easily understood that this report can deal only in general terms with the results of these loeal investigations.

Printed somrees of information have been used, and confercnees have been held both with groups and with individuals. By far the largest number of eonsultations hare been held on their own premises with farmers who are obtaining their living from their agricultural work, and who are regarded by their eommmities as somnd in judgment, methorls and ideas.

No serions appraisement of educational needs and ralues has been undertaken, beyond the strict limits of agricultural training adapted to youths from fourteen years of age upward. In fact, attention has been almost exelusively confined to agricultural education suitable for boys, and perhaps for some girls. who intend to follow farming for a livelihood, and who, but for the type of training recommended in this report, probably would follow the practice of a long line of their predecessor's, and drop out of school altogether.

Provision of agricultural education for girls who have passed their fonrteenth birthday has been considered. This problem raises very inmortant questions, both edurational and economic. There is little experience, so far, by which to be guided. It is believed, therefore, that this subject should be further investigated, and that the questions involved can best be answered by actual experiments made in comnection with the agricultural schools and departments proposed in this report. 


\section{Findings in Brief.}

The agricultural and edncational conditions in this Commonwealth are believed to warrant the following conclusions: -

1. Farming in Massachusetts is a highly important rocation.

๑. Massachusetts farming, where most profitably practiced, is peculiarly dependent upon, and responsive to, scientific knowledge and improved methods. Its increasing diversity and specialization, which are such promising elements in its progress, make more difficult the task of preparation for it, and make more emphatic the duty of the State to the boys and girls who are to follow it.

3. Agencies for carrying scientific knowledge and improved methods to adults, and to students of such age and preliminary training as to enable them to meet the usual college entrance requirements, appear to have been both carefully considered and fairly well established.

4. There is a decided lack of, and a pronomeed demand for, agricultural training of a scientific and very practical character, suitable for boys, and perhaps for some girls, fourteen years of age and older, who expect to gain their livelihood from, and to spend their lives on, Massachusetts farms.

5. The growing commercial and industrial school facilities open to boys and girls fourteen years of age and older, tend to lure away from the land and into the congested centers, in the absence of competent and attractive agricultural education, many young people whose natural aptitudes wonld make them, if properly trained, better and more prosperous citizens in the country.

6. Financial aid for agricultural education, snitable for adults and for college students, has for a half-century been furnished by this Commonwealth and by the federal gorermment. State aid for rocational training of secondary grade in agriculture, is, moreorer, entirely in keeping with State aid for independent industrial school work, and to some extent was provided for by chapter 505 of the Acts of 1906 and chapter 572 of the Acts of 1908 .

7. The slow development of secondary agricultural schools, the testimony of farmers throughout the State, and the demand 
for the investigation here reponted which was made by the Legislature of 1:110, alde rvidence of the need of arditiomal lesislation providing for this kinet of agricultural exlneation.

8. Achool committees have long heen anthorized and enpowered to poriste instruction in agrionture in the pmblic elementary and high selools of the State. IThite this training has been nuene likeral and coltural than roeational in its aims and results, it merits the hearty smprent of lexeal communuties in this Commonweraltl.

Instruetion in gandening and in othere natteses relating to the fam should be enemiged and guided in all the elementary schools of the State, where the heme enviromment or the wehool facilities make prestuctive work and persmal observation be the pupils puaticalle.

As an inpertant aid to liberal exhestion in all of the high scheols of the State particularly in these which have a reulal envirenment, guidance and eneomlagement shonld be given, with

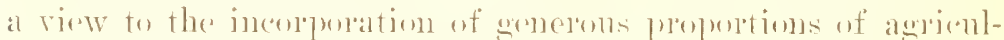

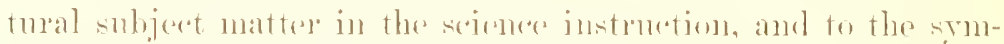
jathetice conerelation of certain parts of the insturetion in English,

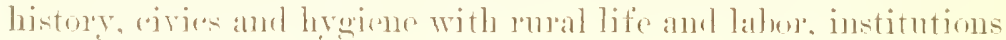
and progless.

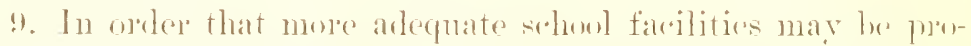

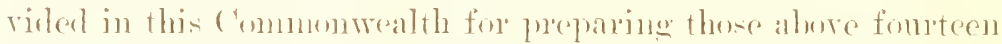
years of age for prolurtive amb protitable famming, voutional

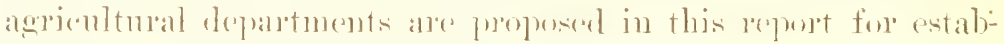
lishment in existing high schools.

The motherls and rocational stamelarels of instruetion for the developusent of surh agrienltural departments have nowhere

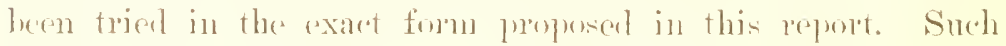
appoximations to this kind of training as lave bern foumd in

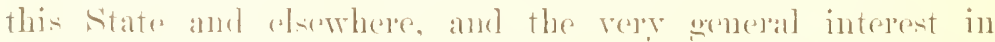

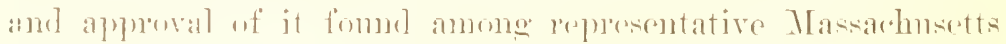

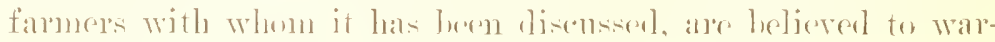
laut giving the department trpe a thenough trial.

The axperimental whalatere of the drpartment type, it will

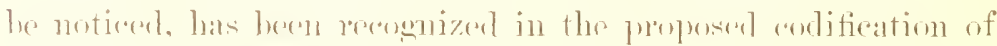

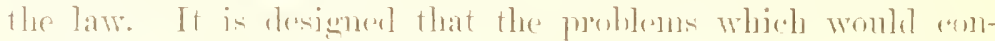

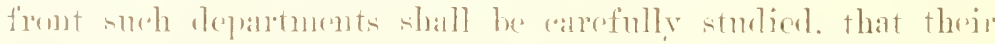
work shall be themenghly dene. and that no department wall 
be attempted where comlitions for sucess are not reasonably farorable.

While annual State aid to the amount of $\$ 10,000$ might make ten departments possible. it is by no means certain that it would be found advisable to estahlish ten departments, or even fire, the first year. On the other hand, if the proposed department type of agricultural training shonld prove in actual use to embody the merit which it is believert to possess, prorision for increasing the number beyond ten could in future be made.

\section{Recomalexdations.}

In view, then, of the needs of the State as we have found then, the following three recommendations are respectully submitterl:- -

1. We recomment that State airl, equal to that granterl any town, or group of towns constituting a district, for indnstrial schools, be continned as at present provided for in the are of any town, or group of towns constituting a district, for the estatlishment and maintenanee of an independent agricultural whool. (Sec chapter 505. Acts of 1906 , and chapter 57. Acts of 1908.)

2. Tre recommend that provision be made for the establishment of agrienltural departments in existing high sehouls, with State aid, and with rigid definition and enforcenent of rocational standards.

3. We recommend that the above provisions shall be considered to be sufficient for meeting the needs of Wrorester, in common with those of all other parts of the commonwealth. and, therefore, to obriate all necessity for special logislation on behalf of that eity.

The above recommendations are, of course, to be interpreted in the light of this entire report.

\section{Proposed Legislation.}

The Board is submitting to the General Compt a proposed codification of legislation relating to industrial, agricultural and lousehold arts erlucation. In that codification is included what is helieved to be ample legal provision for the establishment of a system of agricnltural schools.

For convenient reference, a copy of the proposed codification is bound herewith as an Appendix. 
II.

DOES MASSACHUSETTS FARMING WARRANT

THE ESTABLISHMENT OF 1 SISTEM OF AGRICULTURAL SCHOOLS?

Does farming in Massachusetts offer sufficiently important and attractive careers to warrant the establishment of a system of agricultural scliools in this Commonwealth, to train boys and girls who have reached their fourteenth birthday for farm life and work? The present chapter briefly reviews farming incentives and prospects as they are found in this State to-day.

1. Incentives to Farming in Massachusetts are Many. - In a given farming enterprise there may be blended any two or three, or' there may be blencled all, of the incentives which make farming in this State attractive.

(1) The stress and uncertainties of other cullings lead many to engage in farming. Severe competition and uncertainty as to the future in business have resulted in the purchase and derelopment of Massachusetts farm land. Prospects for a profitable investment, a stable oceupation and a lifelong employment at congenial work are incentires to redirection of effort in such a case.

A section of this State was pointerl out, during the investigation leading to this report, which was said to have been bought up, one small holding after another, lyy "broken-down mechanies." It might be fairly enmilcred one of the least promiwing scetions for farming. The operations undertaken were on a small seale; in no instance on a large one. Tealth and rignr, and self-snstaining life for their children and themselves, free from the severe competition in the trades and industries, were the primary incentives in these cases.

Farming in Massachusets has hecome ineraringly attractive to immigrants who have left the old world and come here with the determination to succeed. These immigrants are not so much peasants as they are pionecrs. They are thrifty and observant; they are quick to adopt new ideas and methods. 
Money is saved and invested. Theirs is a program of hope. As their savings and their holdings increase in valne, their standards of living rise; they begin to educate their children, and presently are on a level with other good eitizens in their communities.

(2) The attractions and associations in the family are strong motives with many. Farm after farm is owned and operated now by the same family, in whose ancestral line it has remained for eight or even nine generations.

(3) The natural charm of the country may be said to be the motive for the establishment of the growing number of more or less magnificent estates in Massachusetts. The North Shore, the South Shore and the Berkshires are noted for the men from the great cities and even from distant States who have sought Massachusetts land for its picturesque actualities and possibilities.

Most of these estates possess well-ronnded agricultural equipment, and have ereated a large demand for skilled gardeners, florists, fruit growers, herdsmen, grooms and trainers. They employ expert farm managers, and supply their own tables with the cleanest milk and the choicest farm, garden, or'chard and greenhouse products. The stables of at least one of these estates shelter harness horse championship winners in international competitions. The owners pay the highest prices for the bestbred live stock, and in notable instances have put their farming operations on a strictly economic basis, as object lessons for neighboring farmer's.

Beside and among these more splendid estates there is a multitude of simpler establishments, maintained on a more modest scale, for like purposes.

Sometimes one hears the protest that such estates are, as a whole, detrimental to the public good. Whatever may or may not be the merits of this contention from the point of view of the community at large, it is eertain that their establishment cannot at present be regarded as detrimental to the interests of those who must be dependent upon farming for a livelihood.

(4) A life pursuit to be found in farming is the compelling incentive of many people who engage in agrieulture. This State has its misfits and failures on farms, as in every other 
line of human activity: but it also has farmers who love, and are finding profitable, the careers on the land which they have chosem. The snecess of the latter is moloubtedly due to two "anses: (a) to a fundamental liking for the land and all the natural acompaninents of its cultivation; and (b) to the cenomic status and prospects of farming in this Commonwealth, discussed in the following section. The investigations on which this report is hased riekled abundant and convineing crictence that Massachnet ts farmers beliere, not only that farming in general offers a desiralle carecr, but also that those who intemel to make farming a life pursuit in this State will find themselves put to no serious lisadvantage becanse their lot is to be alst in this Conmonwealth.

2. Fuming prospects are good, and are stealily improving. Ilaving glancel orep some of the incentives which have led men to engage in farming operations, we may now consider certain facts and figures with regard to the comblition of agriculture in this State.

(1) The agrimultural sensus of Massurhusetts shows that farming propects are sook. The Massarhusetts State census for 190.5 reporterl the value of property devoted to agrientture in general in this State as $\$ 288,15,000$. The annual farming ontput was ralned at $463,110,000$. The erowth of agrixulture in importance is shown ly the fact that in $18 \mathrm{~s}$. the total value of ontput was $\$: 37,073,000$; in $185.5,447,5.56,-$ 000 ; in 189.5, \$59, 580,000 ; and in $190.5, \$ 78,110,000$.

In 190.5 the value of the agrientulual products of Worcester Comnty was reprorted as $\$ 14,279,000$ : and of the city of Worester alume as $\$ 1,4 ! 1,000$.

There is no roaton for believing that State ernsus fignros for 1!)10 womld show rotrogression. In three deartes, enderl in 190.5. the annual value of agricultural products in this State harl practically domberl. The Tuiter States census mar not show lare arklitions to the agrientural popmlation of this Commonwealth, lunt it may reasmably lo expected to show gains. at least commensurate with those of the last generation. in the ammal ralue of Massachusetts agricultural products.

(2) Massuchusetts farmers suy farming prospects are promising. Tost of the conforences hold in preparation for this report 
were personal interviews with Massachusetts farmers on their own prenises, - farmers who are regarded by their communities as thoroughly reliable, and who are dependent on their farming for a living. In all sections of the State the prevailing opinion is that no State offers a better opportmity for profitable agriculture and a satisfactory home life on the farm than does Massachusetts. This was show'u by statements such as the following: -

"We have good land." "Tre have the best markets in the world." "We have good roads and short hauls." "We have excellent shipping facilities, and the cost of shipment is light when comparerl with the cost of shipping produce from distant points." " ITe can generally get enough grod help." "I increase my market garden proluction a little every year: the more I protuce, the more I can sell."

"The cities are growing so much faster than the rate of increase of production from the land, that excessive competition is not to be feared. and prices for prime farm products are bound to continue good and are likely to become better." "The great variety of soils and promlucts is favorable to satisfactory farming, taking one rear with another, in this State." "A keen eye to the markets, and shipment to New York or other out-of-the-State points, when prices rule low lrere and high there, take care of any temporary surplus or silump in home market prices." "For choice fruit there are almost unbelievable possibilities in the home market, with the port of Boston rearly for shipment of practically unlimited quantities, especially of apples, to foreign markets."

" Tre have good libraries, public schools and churches." "The Grange in Massachusets is a splendid organization for getting the farmers together for pleasure and the improvement of their life and work."

Such are the things said by the farmers themselves of the advantages of farming in this State.

(3) The small number of abandoned farms shows farming prospects to be improving. Secretary Ellsworth of the State Board of Agriculture now has in press a report of 160 pages, entitled "Massachusetts, her Agricultural Resonrees, Adrantages and Opportunities, with a List of Farms for Sale." The publication of this report at just this moment is singularly opportune, and malies mnecessary any extended treatment in this chapter of the subject now touched mpon.

Tn his preface Secretary Ellsworth says that his publication 
is issued at the beginning of an exceptional era in Massachusetts a griculture. ... While an effort was made to secure the names of parties owning or controlling strietly abandoned fiums, the attenut was ineffectual, and we are forced to confess that in our belief there are few such farms in the State. Nerertheless, reports confirm the opinion that there is an enormous amount of land lying idle or partly deserted, and that nany farms are not worked to anywhere near their limit.

(4) Improved tilluge makes farming prospects better. Massachisetts land is remarkably responsive to better farming. Land once tilled but now lying for the moment largely or even entirely neglected may well be regarded as a sign post of dormant fertility. Such land is simply lesting. Striking examples of this fact came to riew dnuing the investigation the past summer. One instance may suffice for the present purpose, and the fact that this is turnished by the work of a woman whose farm was visited rendere it none the less significant.

The owner of an intensively tilled farm, with a model dairy and well-developer piggery, poultry, market-garden and greenhouse departments, desired to increase her output. She therefore bought a 20-acre field. This lay next adjoining her own improved land, but had not been cropped within the memory of the oldest inhabitant of that section, - not for at least sixty years, and probably not for more than a century. It was sparsely strewn with wild grass, gray moss, sweet fern and bayber'ry. The former owner had often said that he would keep a yoke of oxen if he only thought he could grow enough feed for them, but he did not believe he could do it.

The past summer, its first season in tillage at the hands of its present owner, this field vielded 10 acres of rye, straw and grain: 250 bushels of splendid potatoes; 80 tons of ensilage, now in the silo; 2 acres of heary field corm, at the time of the interview standing in the shocks; and 2 tons of sugar pumpkins; while at the time the field was visited there were 8 acres in clover, sown in the rye and showing a good "catch," $1 / 2$-acle in turnips, with the remainder of the field laid down to rye again.

(5) Increase of investments in land shows that farming is hecoming more attractive as a business enterprise. Kren business sagacity has led a caterer well known in this State to 
purchase a farm and develop it as an adjunct to his city business. His farm is a strictly financial proposition. Though model equipment and conditions have been established, he does not use it for a summer residence, and his risits to the farm are for inspection and for conference with his manager. Strict accounts are kept. Waste from the catering kitchens is sold to the piggery department. Ponltry, market-garden, piggerry, fruit and dairy products are sold to the catering ends of the combined business. The hooks show that the farm is a paying investment.

"Golden New England," by Mr. Svlvester Baxter ("The Ontlook," Sept. 24, 1910, pages 179-190), is an account of the status and prospects of farming in this section. Mr. Baxter gives the following instance:- -

On a certain Essex County place a Buston business man has gone into apples in a way that ranks the undertaking as a great business enterprise. A single place, with something like 50,000 apple trees, not only cuts a large figmre in Massachnsetts, - eren in the great west it would mean "going some."

(6) With little farms, intensive farming vields large returns. Contrasted with the western prairies, the smaller ficlds along and among the hills and streams of Massachusetts hare seemed to some impossible of profitable cultivation. By then it is eren asserted that Massachusetts is "not an agricultural State." Such a remark is met by the Massachusetts farmer with a blank look of amazement. He has no doubt that farming in this State is a permanent and an increasingly important rneation. He knows that fundamental to adrancing agriculture is a market commensurate with its output; and he sees the manufacturing towns in his neighborhood growing with a rapility almost beyond belief.

Even in the west, not the enormous holding, but the smaller one is now recognized as the more promising basis for the most permanent and profitable agricultural production. Eridence is abundant that the little farm may vield large returns. One of the tidiest bits of farming seen the past smmmer was on a 10-acre farm, of which part was in pasture and only abont. fi acres were minder cultivation. Some of the land was tilted on 
edge, in typical Tin England fashion. All of the fields were more or less irregular in their bondaries. and from some of them artloads of stomes had been removed, with more to follow. The land was "kept busy." Market gardening was the main feature, but there was fruit; and thre wore "side lines" uf dairying and pontty, for utilizing "elippings" and unsalable remmants of the principal products. This farm is yielding a protit of $\$ \bar{r}, 000$ a year.

()ther farms risited, which to the macenstomed exe might look suall, are yiclding net returns of from $\$ 2,000$ to $\$ 10,000$, and aren $\$ 12,000$, a year. Greater thrift and satisfaction in work well done one conld not hope to find in any State.

Mr. Baxter, in the article abore aited, gives the following instances:-

A half-acre strawheriy patell, . . y yelds 5,000) quarts, worth $\$ 625$. Elevern humdred dollars have come from an arre and a half of cantalonps. There are thousunds of arres in asparagns in Massachusetts alone. with untits of $\$ 300$ or even $\$ 600$ an acre. An Italian makes from $\$ 4,0001$ to $\$, 5,000$ a year oft of 4 acres in market gardening. Five acres in peiches lave yielded $\$ 2,500$ in one year. Apples! That is a story in itself. And flowers? Well, there is a lady on cape Cod who makes $\$ 200 \mathrm{or}^{\circ}$ so erery summer un a patch of sweet peas little bigger than a eity bark yard. As for potatoes and con'tu, there are mumerous big records.

(7) Comparison of productivity with other States shows farming prospects to be comd. Secretary Ellsworth, in the pampliket hefore mentionerl, is ontspoken and explicit in his estimate of the agricultural prospects of Massachusetts. This hat prerionsly born intimater, and will more clearly appear from the following passage:-

. . whru ratio of acregate frutuction to agoregate arreage, yield ler acre of certain "rops and chararter uf tillage are considererl, Masiachnsetts ranks farorably with the leading agrioultural States. The following data, gleaned from the latest offocial statistics, ahl strength to this statement:-

Tn 1900 Massarlnsetts had 3,1 7,06t acees in farms, which yielded the previons year $\$ 2,298,27 t$ worth of farm prouncts. As compared with the five leading agrionltural siates, we find California, with nine times this number of acres in farms. prodneing only three times as 
many dollars' worth of farm products; Illinois, with ten times the farm acreage, producing eight times as many dollars' worth of farm products; Iowa, with eleven times the farm acreage, producing nine times as many dollar's' worth of farm products; Kansas, with thirteen times the farm acreage, producing four and one-half times as many dollar's' worth of farm products: and Texas, with forty times the farm acreage, producing five times as many dollar's' worth of farm produets.

Further, from the estimates of the United States Department of Agriculture for 1908 these striking figures are olbtained: the arerage production per acre of Indian corn for the United States was 26.2 bushels; for Massachusetts, 40.4 bushels; of oats for the United States. 25 bushels; for Massachusetts, 33 bushels; of potatoes for the United States, 85.7 bushels; for Massachusetts, 95 bushels. In relative rank of production per acre, Massachusetts stands among the States, for corn fourth, for oats thirteentl, for potatoes twelfth. When compared with the leading States in these products, Massachusetts ranks in production per acre, for corn fourth, for oats first and for potatoes second.

The crops used for comprison are not the leading agricultura! products of Massachusetts, but the figures indicate what the intensive metlods of agriculture practicer by her farmers is bringing forth from the soil. While comparative figmes for wher States of those products which are most valuable to Massachusetts are not available, it is safe to assert, withont fear of contradiction, that, whereas the production per acre of such field crops as corn, oats and potatoes is relatively high, the production per acre of fruits and other regetables which respond so much more readily to intensive treatment is not exceeder by that of any other State of the same or higher latitude.

8. Conchusions. - It is believed, in short, that the experience of those who are snecessfully engaged in farming here, and the economie status and prospects of farming in this Commonwealth, show conelusirely that exceptional success awaits the mork of the exceptional man or woman in this field of ecomomic actirity; and that farming is bound to afford a profitable and satisfactory living for the arerage boy or girl who enters this field with a thrifty, alert and progressive spirit, and with a proper preliminas'y edncation.

At the beginning of the investigation lading to this report. the question was raised as to whether a system of agrienltural schools would be likely to result in inereased raluation of taxable property on farms, and thus return directly to the public treasury at least some portion of its cost. One farmer put the gist of the auswers of all his fellows into the suceinet reply, 
that it did not take the assessors long to discover any improvemonts that he made on his farm as a result of better methods. Finally, it appears that farming in Massachusetts, riewed from the standpoint of both its present status and its prospects, is a calling the sncessful pursuit of which requires a knowlcdge of the science that lies back of the practice of agriculture as a handicraft; that, in order to secure a widespread productive and profitable agriculture, it is necessary that rocational schools supported and controlled by the public should train the youth in the best methorls of farming; and that farming in Massarburetts is a calling of sutticient importance to justify both local and State support of those forms of education that will effectively prepare boys, and, to sone extent at least, girls, for it. 


\section{III.}

\section{THE SYSTEN OF AGRICULTURAL SCHOOLS RECON-} MENDED FOR MASSACHUSETTS.

It was pointed out in the previous chapter that the condition and prospects of farming in Massachusetts seem to justify a system of agricultural schools. The question arises as to what types of schools are desirable for this Commonwealth. Two promise to be effective. These are the separate or independent agricultural school, and the agricultural department in the public high school.

\section{Separate Agricultural, School.}

(1) Definition and Examples. - The separate agricultural school aims to promote, by education, economic farming. Its location, plant, staff and courses of training are determined by this object. Such a school may, or may not, be on the same site with an institution of different grade or type. Whatever its proximity to other kinds of institutions, it requires a distinctly agricultural atmosphere and a farming environment.

Instances of this type are: Minnesota Agricultural School, St. Anthony Park; the secondary agricultural courses at Guelph. Ont., and Storrs, Conn.; and Smith's Agricultural School, Torthampton, Mass.

(2) Minimum Standards. - Present experience seems to show that schools designed to give rocational education must meet eertain minimum requirements in order to do effective work. The following may be given as examples of such requirements for the separate agricultural schonls:-

1. Location and Plrant.-a. Accessibility. - The economic operation of a separate agricultural school and its usefulness to the State depend upon a considerable enrollment of students. Experience demonstrates that an attendance of less than 100 means cither an excessive per capita cost or inferior teaching. The spot selected for it, therefore, should be easily reached from a considerable farming area. 
b. Acreage and Tariety of Soil. - The land should be typical of the surromuling region, and permit of demonstration of the best methols of farming for that section of the State. If not a special school, deroted, for example, to market gardening, it should have a sufficient acreage and rariety of land for landscape garlening, forestry and general farm tillage, as well as for gardening and nursery plots.

c. Buildings. - The buildings should be especially designed and gromper for the peculiar work of the school. Such buiteings as harns and poultry houses shoukd be of the kind any farmer with a moderate amount of capital would wish to erect as parts of a conrenient, sanitary and practical plant.

d. Live Stoch.-- Quarters for all kinds of live stock suiterl to the locality shomld be provided. The school might, or might not, own the live stock dealt with in clase demomstrations. The best obtainable specimens of the hreeds sturlied shonld be sern and handled, and proper accommolations for keeping them thould make it easy io borrow or hire the animals when neederl. Wh'n not filled with live stock, these quarters would still be on riew as models of their sereral kinds for honsing and cariug for the various types of farm animals.

e. Other Equipment. - The equipment should be morleru: and raried, hut every piece should be applicalle to some project in practical farming. Submitterl to the test of practical farming, much, for example, of the equipment usually found in high sclowl science laboratories wonld be onitled and othes rquipment wuld he selected. I museum for collerting out-ritdate farm implemerets and machines would serve a most excellont informational purpose; but the main object shomld he to provide the bent models of implements and mathines for pres(nit eemomic use.

B. Sinpurt rand rontrol. - The enst of such schools is large, generally too lispe to be provided ly a singlo commmity. In gowed schools the initial cont of the plant, inchuling adequate land, huildings and erguipment. and of providing for from 100 to 150 stulents, has beru firm $\$ 40,000$ upwart. The annual maintenane cost las varied from $\$ 8,000$ upward. In some eases the

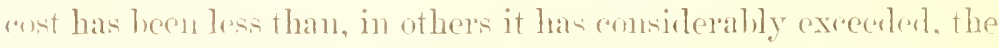
figures here named for both plant and maintenance. 
a. Local Support. - The school should be estahlished and equipped by the local community, - by a town or city, or by a group of towns or cities, or towns and cities formed into a district. This should insure economy of construction and adaptation to local needs. The local community should provide, also, one-half the cost of maintenance.

b. State Support. - One-half the maintenance cost of these schools should, in accordance with present statutory provisions, be borne by the State. In consideration of State support, the school should be subject to supervision and approval by the Board of Education as to organization, control, location, equipment, conrses of study, qualifications of teachers, methods of instruction, conditions of ahmission and employment of pupils and expenditures of money.

C. Conditions of Admission and Promotion. - 111 applicants for admission above fourtecu year's of age should be receired, provided, after a brief probationary period, they proved able to profit by the instruction.

Advancement from subject to subject or from class to class in farming subjects should be dependent solely upon the proficiency of the pupil in such subjects, and not upon his standing in English, history or other similar studies. Upon withdrawal from the school, whether upon graduation or earlier in the comre, every student shonld be given a certificate containing a statement of the work which he had satisfactorily completerl.

D. Teaching Staff. - a. Tocational spirit. - The teaching staff must be in complete sympathy with the rocational purpose the school is designed to serve. The instructors should be chosen from those who have found, or who intend to find, their life work in this field of education.

b. Fitness. - Aptitude for teaching fourteen to eighteen year old boys of exceedingly practical interests and tendencies is indispensable. One may suceed as a teacher of men, and fail as a teacher of boys. One may suceed in a cultural school with book subjects, yet utterly fail in teaching practical subjects in a vocational school. To natural aptitude must also be added special training in the science and in the practice of different kinds of farming.

c. Originality and Resourcefulness. - In derising and lead- 
ing the students to work out definite farming activities, the teachers must be able to bring to bear in new and largely untried ways knowledge of the general field of agricultural science and practice. Having selected things to be done, it must rest with - the teaching staff to find help for doing these things, - in related portions of mathematics, chemistry, physical science, biology and economics.

d. Co-operation. - One teacher must help another. Unity of effort is no less important than is unity of spirit. All eyes must first be fixed on the things to be done; then, towards doing those things in the most intelligent and skillful manner, each nember of the staff should contribute his particular part.

E. Course of Preparation for General Farming. - Courses shonld be provided for boys and girls. The girls should be trained in all household arts and affairs. They should also be allowed, if not reguired, to take training in such subjects as gardening, poultry raising, bee-keeping and ornamental planting. Here. however, only the agrienttural course as designed for the boys is discussed.

a. Length of Course. - I four-years conrse for boys entering at fourteen should he provided. Each year, however, should txe complete in itsclf. This would permit of withdrawal with profit at the end of any year. It would permit, also, of admitting for a year, or for two years, an older student who could not give longer time to the work.

b. Length of Session. - The year should begin nut earlier than the middle of September, and close not later than the micldle of June. This wonld make possible a srhool year of thirtysix wreks, or a school year of some fifty weeks, under a co-operative hme and school plan. The period of each school day deroted to the school study and actirities should probably not exceed six hour's as a maximum. The time before and after the datily sehool session and on Saturdacs would afford proper opportunity for day-to-day work at home. where continuity of effort, as in the carc and handling of live stock, is a necessity.

F. Principles to be observed in Methods of Instruction.-a. Interest. - The essential minimum of the study of books chould be combined with the maximum attention to practical work. Things themselves should be handled, studied and rea- 
soned about; operations, many in number and of an extremely practical nature, should be performed. General rules, statements or ideas may follow fresh handling of concrete detail, - they should seldom precede it.

b. Responsibility. - Active relationship to real life, and persistent participation in farming aftairs while the student is yet in school, should be fundamental aims. Methods should be developed, therefore, which involve student ownership and home cooperation.

G. Gradation of Farming Activities or Projects. - a. Firstyear projects. ${ }^{1}$ - The first year should deal mainly with projects whieh involve an elementary knowledge of soils and plant life, together with the mathematies related thereto. Kitchen garden regetables and flowering plants should be grown.

b. Second-year Projects. - Certain second-year projects should involve extensive experimental study of agricultural botany; others should involve the scientific principles and the mathematies necessary for successful work in handling the smaller farm animals, such as poultry, pigs and bees.

c. Third-year Projects. - Fruit-growing and market-gardening projects should receive ehief attention in the third year. The first prineiples of agrieultural chemistry and the manipulation of the laboratory apparatus required for their elneida. tion should be mastered. Some attention should be giren to the mathematics required for field survers, for business transaetions and for figuring the cost of producing and marketing the crops under consideration. A eareful study should be made of the pumps, engines and other mechanical devices necessary for spraying.

d. Fourth-year Projects. - The major projects of the fourth rear should deal with animal hubandry, inchuding dairying. There should be one term of advanced agricultural ehemistry. Tere the greatest maturity in age and mental grasp have been attained. The largest money values are here involved, and the most difficult problems of land fertility, rotation of crops, rations, breeding and animal diseases are here to be finally dealt with. Farm management, law of contracts and farm accounts should be studied.

1 The word "projeet," as here used, is defined in chapter $\mathrm{V}$. 
e. Possible Modifications. - It is believed that the above gradation of projects hy years would be found a good ontline for the derelopment of courses of study suited to local needs. It wonld afford much tlexibility as to details of schednles and instruction. At the same time it is recognized that other ontlines worthy of approval may grow from year to year ont of the work of the separate agricultural schools.

1I. Cood Citizenship. - Nlomg with the major farming interests of these four years there should be developed the interests and powers of good citizenship, through reading, discussion of current events, and the clear and logical expression of ideas in writing and public address.

I. Home Residence and Wrort. - a. Home Inflnence.Students should reside at home. The age of the students makes this desirable, if not imperative.

b. Home Experimentation. - Residence at home shonld vastly multiply the benefits of the school. There wonld be opportmity for the ordery but immediate trying ont of new ideas and nothods, where otherwise habits of postponement would be formed. From day to day the teachings of the school should be subjected, on a molest seale at least, to the practical tests of the home farm comlitions of every stmlent. In $n^{\circ}$ other way can the maximum ralne of such a school be realized.

c. Howe Credil. - Home work shonld he provided for in the system of marking, and full eredit for it should be given towarels gratuation. For promoting a keen spirit of enulation, watherings of pmuils, parents and others shonld be held at the lust farms, or where the teachings of the school are best exmplifiert. Prizes for exellene in home work shombl be : warded.

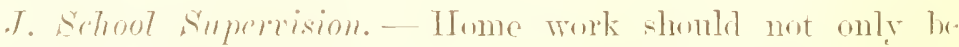
arlvised on sugesent, it shomb also be atively supervised from month to month. At least one instructor shonld be emploved for this purpose thromghont the growing and barresting seasons.

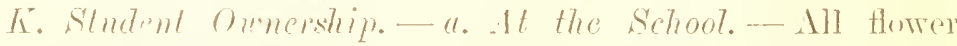
and regotalib gamlening products of the stment plots at the shool shomld he the property of the stutents, provited the fluts he regularly and properly cared for throughont the smm- 
mer. The plots should be of such size that abont one-half day a week during the summer would suffice for their eultivation. Experience has shown that plots of this size yield crops of sufficient value to repay the students for their work. IIre school ('ontrol should be absolute.

b. At Home. - Parents should give the students at least modest property rights at home, and exact proportionate responsibility and industry. Part of the garden might be giren or rented the first year; a pen of poultry, a pen of pigs and a hive of bees, the seeond; part of the orchard, the third; and a cow, the fourth. Aceurate accomnt of ontgo and income should be kept in all cases.

No better test of the practicability of the trachings of the school could be mate. Though school control is likely to be more or less modifierl by home control, good results should still be had by proper ehoice of projeets and harmonizing of interests.

L. School Operations and P'roducts. - a. School operations should be primarily for educational purposes. I barl method may be followed, and beside it an approver method; the profit of one may, or may not, offset the loss of the other. Both together make a perfect demonstration for purposes of instruetion.

The results of such demonstrations should be followed and observed at proper intervals by the students. They should be required to report at the school on the call of the instructor for noting the demonstration work of the school in comection with the instruction they have severally reeeived.

b. School Products. - Apart from the productis of the firstyear gardening work, all products of the school farm should be disposed of for the benefit of the school. The operations of the shool departments should be under the direct control of the instructor who teach the subjects the departments represent. deenrate profit and loss aceounts for ach department shonld be kept.

M. The special School. - I separate agricultural school might be either general or sperial in character. If general, such a rehool woukl mulertake, usually by a four-years course of training, to fit its pupils for at least the general lines of farm 
production practiced in the surrounding territory. If special, a separate agricultural school might limit the length of its course to one or two years, and confine its instruction to a single specialized line of production, such as market gardening. Such a special school might receire sindents after they had spent two or more years in an agricultural school deroted to preparation fur general farming; and it might also admit older students without previous preparation in a general school, if they were able to profit from the training offered.

N. More Advanced Education. - If on graduation a student should desire to enter the Agricultural C'ollege, one or two years of further study at his local high sehool should enable him to meet the conventional college entrance requirements. He might have to enter conditioned in one year of French or German; but a condition in such a subject could be easily remored, since credit should be giren for his extensive agricultural training.

(3) General Observations. - That a thoroughly vocational eduation in agrienlture can be given in the separate agricultural school. where properly aquipped, has been sufficiently demonstrated by expericnce to he beyond the range of uncertainty. As noted before, howerer, snch a school in this State shonld he so sitnated as to lie easily accessible to 100 or more pupils; its plant would he expensive and its maintenance cost by no means suall.

The separate agrionltural school, as herein discussed, might be a local school, readity acressible to a considerable farming population, whose pupils lived at home and secured a part of their practical training through the directed performance of their duties on the home place; or it might be a boarding school for pupils gathered from a comsilerable area.

Snch a local school is impracticable in agricultural areas interserted by mountains and pasture lank, where but a comparatively small nmmber of suitalle pupils are within daily travelling distance of a central point. Many communities of this type exist in Mascachusetts.

Many towns or groups of towns, so sitnated, are able to maintain only moderate-sized high schools, and have within easy reach only a limited number of students. The taxable valnation 
of these small centers of population would forbid the existence of so expensive an institution as the separate agricultural school. In a system of agrieultural education designed to meet the needs of the south of the entire Commonwealth, it would probably be necessary to provide either the boarding school of agriculture or the agricultural department in the public high school, for the training of the young people of the isolated communities.

The boarding school of agriculture is worthy of consideration, because of the attention which it has received in other States. It does uot, however, seem necessary to adopt it under the conditions which prevail in a compact State like MLassachusetts, where distances are so short and transportation facilities are so good. Rather it is believed that liere the separate local agricultural school (without the boarding feature) should scrve the needs of thickly settled farming districts; and that the agricultural departnent in the rural ligh school, as described in the closing part of this chapter, should, instead of the boarding school, train for effectire farming those who live in the more sparsely populated farming communities.

\section{Sepafate Agriclutural Tepartuext.}

(1) General Obsertations. - In preparing this report a careful analysis has bern made of the conditions of the snaller communities as related to the necessary couditions of rocational education in agriculture, with the result that a type of school found dereloped to some extent in Canada suggests itself as being the most feasible means of meeting Massachusetts requirements. This has been styled the agricultural department of an existing high school, and contemplates the building up within an ordinary high school of a rocational department, corresponding to the rocational departments in commercial studies found in some village high schools.

From facts and conditions adduced below, it is heliered that in some lncalities in Massachnsetts, under very careful supervision, such agricultural departments would be possible, ant could, if rightly administered, give genuine vocational training in agriculture. The "part-time work," or school and homefarm co-operative method, discussed in chapter $V$. of this report. 
would. it is beliered. make such departments rocationally cffective as prepratory comros fur productive farming in this Commonwealth.

(๖) Definition and P'resent. Itempts. - Tocational aguenltural elucation as a separate department in a high school should be as distinctive in its object and atmosphere as is the separate agrienutural school. Such a drpartment would best be estahlished in a scomdary school whioh had a farming envimoment and an ahumlance of realily arcosible illustrative material, in raripties of fam land, equipment, uperations and products.

There are fourten departments somewhat of this type in the Province of Ontario: six estahlished in 1906, two in 1908, three in 1!o! and three in 1510. It is intemled to derelop this work mutil every comnty in that provine has been covered.

Work of like nature is now bring given its first year of trial lus the Frionds' Plooningdale Aearleny, Bloomingdale, Parke Comnty. Tndima. The practical compes in farm management estallished hy the Agrienttural Guild of the Tniversity ot Chicago, in 190S, utilize for practical experience farm equipment privately owned and land operated for economic purposes, as distinguished from land and rquipment provided and maintainerl by embroment ol public fumds.

(:) Minimum Stundurels. - The agricultural department must maintain minimm standards of similar cluarater to those fixcl for the separate agrioultural school. An outline is here given of vital factors for the suceess of smel a department : -

1. Linsmetor. - There shomlet lo at least one smecialist for instruotion in agrinulture. This tearlor shomld be a man.

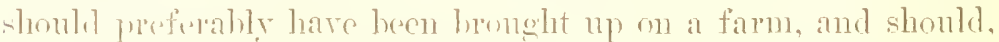
where practirable, he a gratuate of an agricultural rollege. Tn short, le shomld be, first of all, practical, a man interested in

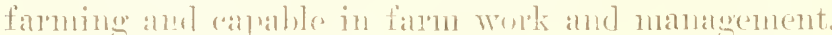

IFis time and attention slonld be devotol exrolnsively to farming suljects. Ilis service shonld be rendered throughout the growing and larresting seasons, in part as supervisor of school projects at the lromes of the sturlents, in part as teacher of agrionltme at the suhool. The might also, if requested to do so. act as arrisol anomg farmers in the rionity of the school. 
B. School Quarlers and Equipment. - a. Class Loom.- I class room should be given this instructor for his exchusive use. This should be on the ground Hoor, or in a high, well-lishted liasement, and shomld he such as to permit of in-door demonstrations of farm animals. implement and nachines. It might, or might not, be in the high school building.

b. Equipment and Ippurtenances. - Tis equipment should at least include a Babcock testing ontfit, seed-cor'n germinators, special agricultural physics apparatus, individual sets of gardening tools, hot beds and cold frames. Gremhonse spare, though not more than a 6-foot by 30-foot lean-to, heater from the legular school-heating plant, would be an advantage; as would, also, be an acre of land for garden, nursery and demonstration pluts.

c. Headquarters for the Instructor. - In oftice shomld bo provided. This slould be large enough for a library and reading room, and fitted up for such nse. There should be furnishor in this room as complete a file as possible of books, bulletins and periodicals on farming specialties.

C. Home Equipment and Co-operation. - Practically all the materials, implements and animals required for demonstrations should be brought to the school by the students, or should be examined on thrifty farms not too far distant. Everything cxamined would thus be part and parcel of actual farming ontfits: each implement, animal and building would represent some farmer's julgment and money. The school wonld at erery foint be dealing with definite economic propositions.

D. Conditions of Admission and Promotion.- - Boys above fourteen years of age should be admitter to the work of the agrienltural department of the high school when, upon trial, they show thenselves able to profit by the training, eren thongh they have not satisfactorily completed all the work of the elementary school. Girls of the same age might attend certain classes. It would be necessary, as is pointed ont at another place, for those pursuing the work of the agricultural department as an elective conrse to take all studies save the art and seience of agriculture in the regular high school dasses. To student should be prevented from attending the agricultural classes or 
be deprived of promotion in them by inability to take high rank in other subjects.

E. Coursc of Study. - The agricultural department in the school should offer training in the practice and the science of agriculture. The course in agriculture should be electire to the regular pupils of the high school, and, as before saiul, should be open to those above fourteen who intend to be farmers, even though they might not be able to pursue sncoessfully rertain other branches of study offered by the school. Legular pupils pursuing the course in farming should he premitted to substitute satisfactory work therein for the requircments of the school in such cultural subjects as Latin or German, or for certain comrses in physics, chemistry and biology.

In this way it would be posible and adrisable that regular pupils, pursuing, as a legitimate part of their stuly, the course in agriculture, should at the cluse of a four years course graduate with their fellows, and receive a certificate or diploma setting forth the work which they had satisfactorily performed.

The school comro should permit of contimuous work at home. morning, evening and on Saturday, as in the separate agricultural school.

a. Dominant liotive.-- As in the separate school, the atmosphere and the dominant object in the agricultural department should be agricultural and rocational. Nuch of this atmosphere might with profit be extender to other departments of the school. Contact with farming oljects and activities would vitalize the instruction in the regular courses in science and in manual arts.

1). Crouping Studies aud Students. - By putting first and sement rear students together in one class, and third and fourth together in ansther, ench stndent would he given double the anoment of distinctively agrieultural training by the instructor which would be presilile wre the sturlents handled in four divisions instrat of in two. Jy the sane means the efficieney and (nthusiasm of the teacher would he multiplied. In alternate years the cueroy and attention of all conld be concentrated now on animal hushandry and then on horticultural subjects. 's vire versen. 
c. Winter School at the Agricultural College. - Moreover, the regulations should permit a student who could meet the age requirement to take winter short courses, at least during his third and fourth years, at the Agricultural College, with no prejudice to graduation with his class; that is to say, credit for a short course at the college should be accepted as meeting in full the winter-term demands of any year at the school.

d. Schedules of the Instructor and Students. - The program should schedule the instructor for from sixteen to twenty periods a reek during the fall and spring terms, and allow the winter term for his racation. 'The instructor', in close comection with his class instruction, shonld be scheduled for inspection and advisory work at the homes of the students and among other farms throughout the summer.

e. Transfer of Students to a Special s'rhool. - Should a special school for such training as market gardening be established, with a one-year or a two-years course, a student desiring the special training of such a school might be transferred to it at the close of the second or third year of the general farming course of the agricultural department of an existing high school.

F. Support and Control. - a. Slate Support. - The salary of instructors for such departments would probably rary from $\$ 1,000$ to $\$ 1,500$ a year, and shonld be paid in part l,y the State, as elsewhere proposed in this report. (See Appendix, page 100.)

b. Local Support. - Quarters and equipment, and the necessary adjustments of curriculum for providing a well-balanced course of study, inclusive of the agrieultural subjects, should be furnished by the local anthorities. If the local school possessed wood-working, forging and drawing equipment, correlation of the manual arts work with farming would add decided value to the work of the agricultural department. The local anthorities should also pay one-third of the instructor's salary.

c. Locul Committce. - This department might be risited by a special local committee interested in practical farming, and the adrice of such a committee might be sought in dereloping this branch of the work of the school.

d. State Supervision and Approval. - 111 matters relating to organization, control, location, equipment, courses of sturly, 
qualifications of teachers, methods of instruction, conditions of admission and employment of pupils and expenditures of money, while immediately in charge of the local school authorities, should lie snbject to supervision and approval by the Board of Education.

G. More Adranced Training. - A student who had decided to go to college should find the same opportunities open for preparing himself for college entrance as does the student in the separate agricultural school. An unusually capable boy might carry a course in mathematics or a foreign language in the regular classes of the school while taking his agricultural course. On completion of his agrienltural course, one additional year of study would perhaps suffice for completing his college preparatory work.

Up to this point this report has discnssed the farming sitmation in Masachusetts that scems to justify a system of agricultural edncation for the Commonwealth, the types of rocational schonls in agriculture that seem to be advisable for such a system, and the standards which should be insisted upon in order to make their work effective. 
IV.

CO-OPERATION BETUEEN SCHOOL AND HOME FARM NECESSART TO AN EFFECTIVE SISTEMI

OF AGRICULTURAL SCHOOLS FOR MASSACHUSETTS.

The previous chapter discussed the separate agricultural school and the agricultural department in a high school as desirable types of rocational school education in agriculture for Míassachusetts.

It is the purpose of the present chapter to point out why co-operation between the school and the home farm is neessary, in order to make the rork of such schools effective.

Tocational education is education that has for its controlling purpose the fitting of persons of either sex for definite callings or pursuits. Vocational schools of every type are coming to a recognition of the fact that practice and thinking about the practice, practical and technical training must go hand in hand in effectire rocational education.

The reason is not far to seek. Most people learn better by seeing and by doing, than from books. The experience of a considerable portion of the pupils in industrial and agricultural schools proves conchusively that many persons who have been umable to master principles and theories as taught by the ordinary method of the book, have large power of mastering principles when these are approached through the background of their daily employment; and that, best of all, they possess large capacity to retain and apply knowledge so taught and so comprehended.

Practice and thinking about the practice constitute the key to the situation. Industrial and trade schools are securing the needed practice for their pupils to-day, either through school shops which they are endearoring to make economically productive, or through the actual wage-earning occupations of the pupils. Thinking about the practice is spenred by a propery selected and adjusted comrse of closely related studies 
at the school in which part of their time is spent. The shop provides in illustrations and practical work the raw materials; the sumol, the finished educational product.

Farm Boys may be farorably placed, but require Concurrent Practice and thinking about that Practice. - Boys and girls who expeet to follow farming for a living probably are not exceptions to the general rule. Vocationally effective education for them, also, must involve an intimate relationship between practical and technical training.

Related Study at the School. - The question now arises. Where is the boy to secure correct experience in farming? It will not be difticult for the school to give related scientific knowlerlge, provided the pupil brings to it a lackground of experience in agricultural activities that enables him to assimilate it, and provided he is able, throngh his practice on a farm of some type, to fix the principles and theories gained in the school room.

Previous Farm Practice not Sufficient. - It seems to be clear that the pupils of an agricultural school do not, as a rule, bring to their studies about agriculture a body of previons farm experience which the school can utilize in giving a working mas. tery of the principles and theories that lie back of the best practice. The greater number come from farm homes where they may, or may not, have been fortunate enough to receive directed practice in scientific agriculture. There is at least a slight morcment from city to comntry. It may be expected that a small portion of the enrollment in agricultural schools of scomdary grade will consist of city and village boys who have had no training in the rontine of the farm. In order that such boys may bring to their training something like the same atrantages possessed by the comntry-bred pupil, they should, if possible, previous to entering the school have spent at least one rear on a farm. While this discussion is primarily concerned with the enmontry-bred boy, it is, in the principles it lays down, equally or eren more forcibly applicable to the eity or village boy who has farming aspirations.

The previous farm experience of the comntry-bred boy may have been directed by a farmer who has been too hard pressed 
by his own farm routine to reflect on his own practice in agriculture, or to direct the work of his son so that it might be most educative fron the rocational point of view.

It is significant that many of those who are most desirnus that their sons shall receive agricultural education through the instruction and direction of the school are among the most intelligent and prosperous farmers in the Commonwealth. They clearly see, for the reasons given in chapter VII., that eren the best farmers camnot expect to be the best schoolmaster's in this line of training.

The condition of Massachusetts farming in general is not satisfactory to the leaders of agriculture nor to the community at large. This means that most farm boys, so far as they bring farm experience to the school, are more likely to have been brought up to use bad or indifferent methods than to use the best.

Moreover, the boy of fourteen as a rule has been too young to have been able to reflect seriously or extensively on the problems comected with the agricultural activities which he has observed or in which he has had a part.

It is possible, eren in the absence of closely related practice, to give much effective vocational training in the sciences related to different farming operations to those of mature mind who have had experience in them. A farmer, for example, who had formerly kept a herd of cows, might attend a course of instruction in the principles of scientific dairying: By this means he might make a second renture in that field more intelligent and more profitable. No one will question, howerer, that the dairyman who was able to put into immediate effect in his own herd the scientific knowledge gained in such a course would acquire a greater working mastery of the principles that lie back of the successful pursuit of his calling.

It scems to be clear, in short, that the more or less elementary. more or less undirected or misdirected, more or less undigested farming experience of the country-bred child cannot, in the absence of additional practical training, be made a safe basis for the effective teaching of agriculture as a rocation.

It is true that, on entering the agricultural school or an agricultural department in a high school, that boy or girl must 
derive greatest profit who brings to the work the richest store of previous practical farm experience; but even with the best-prepared pupil it will not be safe to suppose that farm experience of the younger year's will be found fixed and vivid in the memory, to be drawn upon at will, as the classroom discussions shift now to one phase and now to another of farming.

Past experience may aid in the work, and will do so to the extent to which that experience was intelligent and to the extent to which it remains rivid. Practical farming and the book study of the subject, coneurrently carried on under the direetion of a specially prepared instructor, appear to be the only certain method of securing these ends. Thinking may refer back to this experience to some extent; it must to some extent anticipate future actirity; but in the main it is lelieved that the training of the agricutural school, to be effective, must at once provide, and thereafter concurrently interrelate, as far as possible, these two supplementary processes, - directed farm practice and study about that practice.

Provisions for T'roper Farm Practice. - How many school authorities secure for pupils seeking preparation for profitable agriculture properly directed experience in farming processes? Agricultural schools of erery type, in order to be effective, shonld, it is believed, provide at least a small equipment on or near the school premises. for observation and demonstration work in correct methods of farming. Such an equipment would be possible in the typical rural community. A few communities may be sufficiently prosperous to establish and maintain agricultural schools equipped with the farming plant, equipment, animals and materials necessary to diversified and effective training in the arts of agriculture. Such an outlay of public money probably lies, if not beyond the resources, at least beyont the ciric power, of the typical rural community which most needs agricultural edncation.

If agricultural schools could be equipperl with extensive school farms. it would be necessary, in order to secnre the best results, that pupils should devote a considerable portion of their time, now employed at home, particularly in the growing season, to directed activities on the school premises. But it would 
be impracticable to withdraw to any great extent boys from service on the home farm for service on the school farm. Furthermore, all the operations connected with the tillage of the soil, such as the care and observation of experimental tracts, lack significance until the seasons of growth and harvest, - seasons that find the school session ended, and the pupils widely scattered and possibly engaged in cultivating or harvesting the crops on the home farm.

As the most promising solution of the problem of securing effective vocational training in agriculture, this report recommends that the home farms of the pupils be utilized in what may be termed "part-time work" in agriculture.

Part-time work in agriculture would be utilizing home land, equipment and time, outside school hours, for practical training supervised by the school. The term "part-time work" is a descriptive expression, brought orer from current discussions of certain forms of industrial training, for use in unfolding the possibilities of this proposed type of training in the field of education in agriculture. Part-time work in industrial education means that the student spends part of the time required for his training in a shop or manufacturing establishment, and part of the time at the school building; both school and shop work, howerer, being intimately related and supplementary to each other.

Part-time work as applied to agricnltural education would mean that the student must spend part of the time required for his education in productive farm work, preferably at home, and part of his time at the school; the farm work and school study to be closely correlated by the school at points selected from season to season or from year to year, and to be given the highest possible edueational value by competent school superrision.

Equitable. - The same canses that have bronght about a widespread demand for co-operation between school and shop in industrial training, make just as necessary similar co-operation between the school and the home farm in agricultural training. Historically, shop and farm at one time gave the fouth all his rocational training. Of late the tendency has 
heen, under the stress of modern conditions, to throw upon the schools almost the cutire responsibility for the industrial and agricultural alueation of minors. It is becoming incrensingly apparent that the schorl camot meet this difficult and expensive burden, unaided. It would therefore seem to be equitable that the schools, should bestow the related theoretical instruction which they are so well designed to give, leaving to factory and farm the task of giring, under expert direction, the practical experience which they are well equipped to confer.

Economical. - Such part-time work would redure the cost of agricultural training of secondary grade so as to place eflective training for the farm within the reach of many communities which would otherwise br mable to secure it. Part-time work would obriate the necessity of sending the boy away from home in order to secure the benefits of agricultural training. The cont of living for the boy would be less at home than at a boarding school. Parents would be deprived of the services of the boy dnring only a portion of the day.

Effective. - Co-operative work between the sehool and the home farm wonld be the most effective known means of trying ont, under the conditions of individual fams orer willely seattered areas, methods which have proved to he profitable elsowhere, as, for example, at the State Igricultural Experiment Station. Such co-operation would furnish the only experimental moans ly which cach boy would tre ont the merits of the hom farm as an agency for producing profits, when treated by the best-known methods; that is to say, part-time work would furnish the only means wherely the principles and methods taught by the school could be powitively adapted by the boy to the exonomic conditions on the farm on which he might spend his working days. Part-time work thus should give to agricultural toakhing the reality of actual life, as but little school training uns give it.

Conclusion. - It is Ir lieverl, in shont, that every purpose of ceonomy in the wallishment amel maintenance of a system of agricultural whols, and of effirioney in the exlucation providerl. would be instured by utilization to the laresest possible extent of home land, equipment and time in the training of bors for the suressuful pursuit of farming in this Conmonwealth. 


\section{THE PART-TIME AND PROJECT IIETHOD NECESSART} TO AN EFFECTIYE SYSTEM OF AGRICULTURAL SCHOOLS FOR MASSACHUSETTS.

The present chapter ontlines a method by which, it is believed, education through the plan of "part-time work" in agriculture, recommended in chapter I.V., may be made effective.

Under the "part-time work" plan, developed into a system for the whole State, center's rould be selected. The instruction would be adapted to the kinds of farming prevalent in the districts surrounding those center's. The practical applications of the instruction would thus be subject to the obstacles continually encountered under the economic farming conditions found in any given district; just as they would, also, be aided by all the influences in this Commonwealth which make for the improvement of farming. The plan, as an cducational process is believed to possess unquestionable merit, because farming activities would readily resolve themselves into what may be termed farming " projects."

A Farming Project is a Thing to be done. - 1. Improvement Projects. - The thing done might contribute some element of improrement about the farm, as constructing a concrete walk leading to the front door, the planting and nurturing of shade trees, the making and maintaining of an attractive lawn.

2. Experimental Projects. - The thing done might be of an experimental nature, as the planting of an untried rariety of fruit, the feeding of an mntried ration, the testing of an untried spraying mixture, or the testing of one or another of much advertised roofing materials.

3. Productive Projects. - Finally, the thing done might be of a productive nature, as the growing of a crop of cher w alfalfa, the growing of a firld of potatoes, the growing of a crop of silage corn, or the production of eggs for the market.

A Farming Project is, further, Something to be done on a Farm, which would involve a Limited and Definite Amount of 
Equipment, Materials and Time, and which would be directed toward the Accomplishment of a Specified and Valuable Result. - 1. Improvement. - An improvement project might be limited, for example, to a given length and width of concrete walk, constructed of a given kind of stone, sand and cement, costing not to exceed a given sum of money, and requiring not to exceed a sperified amount of time.

2. Experimental. - An experimental project might be limited, for example, to the planting of a given number of trees of an untried fruit. on a piece of ground which could well be spared for such a hazard, and involving a cost in time and money which it was felt eould be afforded at a given time for this risk.

3. Productive. - A productive project might be limited, for example, to the growiug of a given area of clover or alfalfa, at a given cost for sect, fertilizer" and labur, and for the securing of a preeitied quantity and value of feeding stuff or roughage.

Fimully, "Faming Projert, as the T'rm is here used, is a Thing to be done on "Fam, which, in the Preparation for doing it and in the rarrying of it out to a Successful Rosult, would involve a Thonough-going Educational. Process. - 1. Improvement. - The improrement project of constructing a concrete walk to the front door might involve the study of the nature of eement; its artion on sand and gravel or broken stone; its resistant qualities to the wather; the seasons at which it conld be used; its cost, as compared with other materials, such as boards, plank, tar, brick, flagging and asphalt; the mathematical determination of the proportions of cement, sand and stone to be used; the geometrical dotermination of the sections into which it should be dividerl, and whether it should be erowned or flat; the gengraphical somres of the raw material; and the market conditions for purchasing cement.

3. Experimental. - The axperimental project of planting an untrick valis of fruit might involve the study of the probable arlaptability of the variety selected to the soil, the climate and the market demands within reach of the farm.

3. Prochuctive. - The productive project of growing a crop of elover or alfalfa might involve the stndy of the varions varicties of clover; the comparative arlaptability of these rarieties 
to the given field on which the crop was to be grown and to the climate of the locality; the most reliable places for the purchase of seed; the best time for seeding; the best time for cutting; the best methods of enring and storing; the mathematical calculation as to the saring in cost of feeding stuffs which the crop would afford; the chemical elements it would furnish in the ration; and the chemical, biological and mechanical effects on the soil in which it would be grown.

A Complcte Definition of a "Project" as here used has Three Elements. - Thus, it will be seen that a complete definition of a farming project as here used involves the three clements of (1) something to be dome on a farm. (2) under specified conditions and for a specified valuable result, and (3) requiring a thorough-going training.

Project Fields or Classes. - There are certain broal, general fields in which numerons projects might be found. Imong these are:-

Vegetable gardening.

Flower gardening.

Landseape gardening.

Oreharding.

Small fruit growing.

Growing of general farm crops.

Farm forestry.

Greenhouse crops.

Production of poultry products.

Beekeeping.

Swine busbandry.

Sheep raising.

Horse raising.

Dairying.

Agrieultural physies and mechanies as applied to farm buildings, drainage, irrigation, and providing and maintaining farm machinery.

Major Projects. - Projects within the above general fields might be major projects. Of major projects, the following may be given as examples:-

1. Caring for the Kitchen Garden. - Under the direction of 
the school, a boy orer fourteen years of age might be required or permitted to cultivate the kitehen garden for supplying the family with regetables or small fruit.

2. Keeping a Pen of Pontry. - Under the direction of the school, he might be required or permitted to keep a pen of, let us say, twenty-five birds, for the purpose of producing a net profit on the enterprise.

3. Caring for a Sclected Part of the Orchard. - Under the direction of the school, he might be required or permitted to care for a part of the home orchard, say five apple trees, so as to improre the quality of the fruit and thus gain a larger net return.

4. Ratising a Specified Crop of Potatoes. - Under the direction of the school, he might be required or permitted to raiss on the home farm an acre, or a tenth of an acre, of potatoes, according to lis age and strength, so as to secure the best possible crop and the largest possible financial return.

5. Caring for One Cow. - Under the direction of the school, he might be required or permitted to eare for one cow in the home herd, with a view to securing from her the highest production of which she was capable, and to determining whether she were vielding an adequate profit.

Major and Minor Projects. - While the above does not constitute by any means a complete list of possible major projects, it is intended to be suggestive of the many and diversified kinds of projects that might be feasible for use in the part-time work mnder misteration. I major project may include a great many minor projects.

Minor Projects are reluted to Major Projects as Parts to the Whole. - Minor projects include all the diversified activities which the boy must ferform in order to bring the major project which he had mulertaken to a surcessful conchusion.

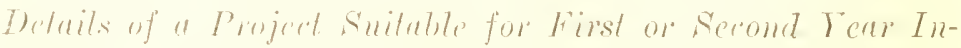
struction. - later in this disension (pages si-40) details are giren of a project suitable for use with thirl or fourth rear sturents. The subject in that case is a staple product likely to be grown on every farm. or at least in every farm garden. 
It this point in the present chapter it is desirable that the possible working ont of the project method of instruction should be illustrated by details of a subject which would be suitable for use with students of the first or second year.

In the list of major projects above given, the second, "lieeping a Pen of Poultry," will, perhaps, best serve this purpose. This project permits of clear analysis. It is sufficiently familiar to make intelligible such technical terms as it may be necessary to use. It deals with a branch of agricultural production found on every farm and at many village homes; yet a branch from which, when conducter on a strictly business basis, it is very difficult to make a profit. It has to do with farm products which are of very great economic importance for the advancement of agriculture in this State; since Massachusetts, while admirably suited for poultry keeping, imports $\$ 25,000,000$ of poultry and eggs annually, and produces less than $\$ 6,000,000$ worth per year. (See "Agriculture of Massachusetts," the report of the Secretary of the State Board of Agriculture, 1909, page 119.)

Owing to the attention now being given poultry keeping by the agricultural colleges and experiment stations, materials for teaching the subject scientifically and practically are increasing, and make this one of the most promising lines of project instruction for school use. Poultry keeping affords one of the best projects for transition from the boy's treatment of animals as pet stock to his treatment of them as rital factors in economic agricultural production.

Important as this poultry project is, howerer, it will, of comrse, be understond that there are many other projects suitable for first and second year use. This project is but a single example of the many which might have been given.

Minor Projects. - Suppose the major project in preparation for purposes of instruction be No. 2, above given, "Keeping a Pen of Poultry." Then certain minor projects necessary for carrying out this major project might be:-

1. The building of a poultry house (if necessary), according to plans and specifications worked out at the schoolhouse. This minor project in turn could be broken up into a number of 
subordinate minor projects necessary to its successtul comtpletion, such as:-

(1) The Selection of a Site for the Poultry IIouse. - Here the decision male might take into consideration:- -

A. The suitability of the soil for poulty culture.

$B$. The condition of the underdrainage of the site, and the possibilities of semring proper surface conditions.

$C$. Conditions of sunlight and shade as factors in the proper care of fowls.

D. Conrenience of aecess from house and barn.

(2) The Adoption of a Plan for the Ponttry IIouse. - Tere the decision male might take into comsideration:-

A. The style of eomstruction best adapted to the purpose for whieh the strueture was to be used.

$B$. The size of the proultry house neressary to the suecess of the project. $C$. The fittings which would be most sanitary, most convenient, and therefore on the whole most economical.

(3) The Materials entering into the Construction of the Poultry Honse (involving kind, cost and availability). - Such questions as these would naturally present themselves:-

A. Should the fomblation be permanent, or temporary?

$B$. What sizes of limension stoek wonld be required?

$C$. Should the flowing be earth, boards or cement?

$D$. Shonld the siding be rough, or planed; matched, battened, or protected by paper?

E. Should the rooting he shingles, matched or battened boards, metal, or some form of patented roofing of the rubberoid type?

$F$. Should the building be painted; and, if so, what would be the bestwearing and most economical color and mixtme? When should the paint be applied?

2. The sclerlion of birds, as determined by the purpose in keeping them (whether for show stock or utility, breeding or egg producing). This minor project in turn might be broken up into a number of subordinate minor projects necessary to its successful completion, such as:-

(1) The choice of Type and Breed. - Such questions as these would naturally prosent themselves:- 
A. Is a meat type of bird desired; and, if so, what is the best breed or type? Is color of any importance?

$B$. Is the egg type desired; and, if so, what rariety? Should the color of the $\mathrm{eg} g$ be a determining factor?

$C$. Among what may be termed general-purpose types, what may be considered the best stock both for egg production and for final finishing as table birds?

\section{(2) The Choice of Breeding Stock.}

A. When should breeding stoek be selected and assembled for production of the eggs required for hatching?

$B$. Should close attention be paid to breed shape?

$C$. To what extent and for what reasons should color and plumage be determining factors?

\section{(3) The Choice of Method of Beginning the Project.}

A. Should the beginning be made with eggs; and, if so, where can the eggs of the breed and type desired be secured? What wonld they cost, and when should they be ordered?

$B$. Would it be more economical to begin operations with incubator chicks a few days old? If so, where could such chicks be had, - when could they be had, and at what cost?

$C$. Should the beginning be made with full-grown birds? Where could they be had, when, and at what cost?

3. The Feeding of the Poultry. - This minor project might in turn involve a number of subordinate minor projects necessary to its successful completion, such as:-

(1) The Selection of the Kinds of Feed. - Such questions as these might naturally present themselves:-

A. When should hard grains be used?

$B$. What are the merits of gronnd grains, as distinguished from hard grains?

$C$. Under what circumstances are mixtmes and mashes desiráble? Should these be fed wet, or dry; and should they be homemade, or bought on the market?

$D$. In what proportions should animal feed be provided, and in what form or forms could it be most economically fed,-in beef scraps, for example, or in green bone?

$E$. Should green feed be furnished? For winter feeding, what quantity, if any, of cabbages and roots should be stored? 
(2) Worting out P'roblems of Feeding. - Such questions as these might naturally present themselves:-

A. To what extent should there be a variety of feeds?

$B$. What relationship do feeding and exercise bear to each other? Should dry grain be fed in the litter, or be fed in hoppers, or both? What differences shonlh there be, if any, between feeding on free range and feeding in confinement?

$C$. What part should grit, orster shells or charcoal form of the ration, and for what reasons?

D. To what extent might feerls be grown at lome, aud to what extent must they be bought on the market?

t. Other minor projects within the major project of "Keeping a Pen of Ponltyy," which might also be analyzed into numerous subordinate minor projects, each necessary to the successful performance of the larger minor project and the major project of which it forms a part, are: -

(1) The production of eggs with profit.

(2) The production of ehicks by incubator.

(3) The ware of chicks by artificial brooling.

(4) The rearing of chicks.

(5) The landling of young stock.

(6) The fattening and killing of ponltry.

(7) The marketing of eggs and birds.

In like manner, everey major project similar to those heretofore described, chosen by the school for purposes of instruction, might be analyzer into the minor projects of which it was composed, both in order that the rarions activities of the boy in the successful accomplishment of the major project might be effectively directed and supervised, and, as we shall see later on, in order that the theories and principles related to the different phases of his task might be given at the tine when they would the most effective from the practical and the educational points of view.

Three factors must, it is believed, retermine the measure of success in any given plan of part-time work in agriculture: (1) the farmer and his farm: (2) the school and its agrienttural supervisor; (3) the boy and his projerts.

1. The farmer and his furm must constitute the fundamental 
factor in the practical training of the boy. There conld he little cffective work in the field of part-time training for the farm without a rensonable spirit of co-operation on the part of the parent.

There are at le ast three ways in which the parent could aid in making the directed farm experience of the boy more edneative: (1) in the use of the home plant: (2) in the use of the home time of the pupil; (8) in giving the boy's projects economic importance.

(1) In the I'se of the Home Plant. - One of the most essential features of the co-operative part-time plan between home and school is that the parent should be willing to devote from time to time, in accordance with the plans of the supervicor or teacher in charge of the work, a reasonahle portion of his buildings, orchards, garden, pasture, forest and other fields, and of his implements and machines, animals and materials, to the directed training of the boy.

(2) In the use of the home time of the pupil the fullest valur of the agricultural course will come from the fullest possible: participation of the boy in the ordinary routine of farm work as usnally carried out hy the parent; but the greatest benefit of the school canmot be had without the nse of a part of the boy's time, during the hours spent at home. for strictly school purposes. The following are a few of many illustrations of what might be the directed use of a part of the home time of the pupils in the pursuit of projerts suggested and directed by the school:

1. The boy might hehr with the milking throughout his course, where the object was to get the cows milked as quickly as possible, and where no records were kept. During certain months of at least one year, the school should require whatever time might be necessary for keeping an accurate record in pounds and ounces of the yield of a part of the herd. This might be limited to the weighing of milk from a single cow, and giving the cow credit for what she produced.

$B$. It might be part of the boy's business to assist in feeding the eows. During part of his course, sufficient time should be giren for weighing the ration and charging at least one cow with what it cost to keep her. 
$C$. In the ordinary routine to which he had been aceustomed in milking, much or little attention might lave been paid to cleanliness of cows, utensils or the person and clothing of the milker. During part of his time in school, the boy should be given whatever time might be necessary for milking at least one cow and preserving her milk under absolutely sanitary conditions, and for sampling the mill for bacteriological tests.

$D$. In the ordinary eropjing of the farm, much or little attention might be paid to leguminons crops. But during one season at least, facilities should be given the puril for growing a pateh of moderate size of dover, and for observing the eftect of introdueing a large proportion of clover into the ration of the cow.

$E$. In the ordinary conduct of the farm, mels or little attention might be praid to the selection and testing of corn for seed. But mior to planting, one season at least, the boy shonk be given whaterer time might be necessary for making germination tests of the corn which it was proposed to plant.

$F$. Also, during one season, the boy shonld be giren control of a portion of a corn field for making an "eal to row" cor'n test; for observing the difference in yield from different ears of corn, all the corn from one ear being planted in one row and all the cor'n from another ear being planted in another row.

$G$. In the ordinary routine of the farm, it might be the business of the boy to tend the proultry. During at least one year, he should be given control of at least one pen of ponltry, and facilities for foeding a balanced ration and trap nesting inclividual birds for comparison of prodnetivity in laying.

$I I$. It might be part of the usual work of the boy to help eritivate and harvest the potato crop. During one season at least, he should be given facilities for testing the value of the use of formalin for the prevention of potato scab, and of the Bordeaux mixture for proteetion agaiust potato blight.

(3) In giving the boy's projects economic importance, the active aid of the parent would again be almost indispensable.

1. Iceping Acrounts. - Whether or not the parent were in the habit of kecping borks, it wonld be vital to the success of the sehool training that aremate acounts of ontgo and income should be kept with roward to certain home projects divected by the schmol. Frory hoy should be tameht business-like methods for carrying on work. Modern husiness methorls moride for discorering exartly whre money is made, and where it is lost, at any stage or in any part of a given enterprise. 
The boy should be given opportunity for testing, nnder his home conditions, the value of methods which have proved efficacious in business. The school, to be effective, must teach economic production in every phase of farm life for which it gives preparation. Noreorer, accounting is necessary to any intelligent comparison of the effectiveness of the method advocated by the school with that of the method previonsly followed.

B. Projects as Business Enterprises. - If the experiences of the boy in the farming projects are to he erlucative to the largest degree, it is believed that they should be conducted strictly as business enterprises. Four methods of meeting the problem of the cost and profit of these directed farming operations would be possible: (a) the parent might meet all the cost, and give the boy all the profit; $(b)$ the parent might meet all the cost, and retain all the profit; $(c)$ the parent might meet all the cost, and share the profit with the boy; $(d)$ the boy might receive the net profit, after the cost of the project had been paid.

From the educational point of view, the last method, by which the boy, after conducting the given project as a business enterprise, shoutd profit only to the extent to which his total receipts exceed the total cost of the enterprise, is believer to be in every way preferable. By this method the boy would learn, once for all. through his own experience, that there can be $n 0$ product without cost, and no profit withont excess of receipts over all expenditures. After such an experience, he would not be likel $y$ to undertake a new enterprise withont a serions attempt to estimate aceurately his probable profit. The boy would be subjected to the prevailing economic conditions under which the home farm must yield a profit, or a loss, at the end of each year of work.

The method by which the boy became on a small seale a farmer or a business man for himself would give the project which he was carrying on a reality not otherwise attainahle, that must heighten measurably his interest in the work and in the related study of the srhonl, and must fix bettel than by any other device the training which he was receiving.

Incidentally, it may be remarked that, as a matter of public spirit, the citizens of the community might do much to further 
the objects of the school by arhnitting the agrienitural instructor or supervisor and his students to their premises, for the examination of animals, machines and all out-door and in-door operations, and by explanation and discussion of their methods of accounting and their improved farming processes. At another point in this discrission the possible ficlds of usefulness to a community of such an instructor or supervisor are pointed out. Effective service on the part of the supervisor in the field of helpful suggestion there mentioned could be rendered only where there was a cordial attitude of co-operation on the part of the people in the community who were desirons of either the improvement of rural conditions in general or the betterment of their own farms.

2. The School and its Supervisor. - Whether part-time work in agrieulture were conducted under the auspices of a separate agricultural school or of a separate department in a regular high school, it is believed that it would require the services of a trained and experienced agriculturist, who shonld derote his entire time to taching the principles and the best methorls of farming. It is believed, further, that largely through this instructor or supervisor of agriculture the school shonld: (1) choose the projects to be undertaken by the boy; (2) direct his work in the discharege of his projerts; and (:) put him in possestion of the principles that relate to them.

(1) In the selection of the projects to be undertatien by the boy, the instructor should take into consideration:-

1. What farming enterprises are profitable, or conld be made so, in the neighthorhood.

$B$. The age of the boy,

$C$. The kinds of projects that wonld be fensible on the home farm.

D. The boy's routine farm work at home.

$E$. The assistance that the father conld afford to give in materials and equipment.

$F$. The suitability of the project to the season of the year.

G. The projects and portions of projects that conld best be carried ont at the school, and the best time on the program of the year for these prarts of the work to be dome.

The problem of the building of a ponttry hone by the boy would be one of the possible minor projects, as before shown. when the larger projert of kepping a pen of poultry was under 
consideration. This problem would naturally inrolve such questions as these:-

A. Would the student have the necessary time?

$B$. Could the necessary materials be provided by the parent or student?

$C$. How much personal supervision of the actual work of construction would be necessary or adrisable on the part of the supervisor?

D. Would profitable poultry keeping on a given home farm require the improved accommodations which the model ponltry honse, built by the student, wonld furnish?

$E$. How far would conformity to the standards set up by the school be necessary in determining what would be a molel type of poultry house for a given farm?

$F$. In what year of the school course should the building of a poultry house be undertaken, in order that the training in poultry keeping might be made most profitable?

G. What time of the year could the student build a poultry louse to best advantage?

The problem of conducting the building of the poultry house as a strictly business enterprise is a project which would naturally involve these questions:-

A. To what extent, if at all, could the boy be required to meet, or be charged with. all cost save his own labor, and be credited with a fair inventory valuation of the completed structure?

$B$. If the parent must adrance the money or materials, what rate of interest, if any, should be charged the boy?

$C$. What method of accounting should be adopted?

$D$. Should such records be kept as would euable the cost of this building to be compared with other similar buildings in the neighborhood, as a check upon the business-like character of the boy's working out of this project?

(2) In directing the work of the boy in the discharge of his mojects, the school must of necessity, it is believed, mndertake the superrision of a portion of his work at home. Supervision of part-time work in agriculture would not be an attempt on the part of the school to interfere with the private management of the farms of the parents. Supervision would, nevertheless, be a continuous effort by the school to assist, advise and encourage the students in applying under home conditions, farm methods which had proved successful elsewhere, and thus to cause the practical training of the students to result in rocational efficiency. 
The instructor would not undertake to supervise all the details of the farm management on any given farm. Daily supervision would be impossible, because of the number of farms to which the work of the school must be extended. Excessive attention to minute details of farm work on the part of the instructor might ereate needless friction between himself and the parent, or might interfere materially with the supervision of a proper amount of project work. It is, therefore, not contemplated.

The school should not, it is believed, undertake to shift responsibility for the economic management of a farm from the shoulders of the parent to the shoulders of the public.

The instructor would undertatic to supervise certain selected major projects and their related minor projects performed by the boy at home. In a given year and season attention might, for instance, be concentrated upon the project of keeping a pen of poultry. Having given the stndy related to this project, the instructor would supervise the application of that study. The following examples illustrate what the character of such superrision might be:-

A. In the bnilding of the poultry lonse, the actual work of putting up the structure might, or might not, be sulvervised by the instrutur. All other elements or phases of the enterprise, as indieated by the outline, should be worked out by the student under the direction of the school.

$B$. The course in farm shop work of the sehool might well undertake to deal with the problem of the actual constrnetion of the poultry house.

C. It would be the duty of the instructor or superrisor to cimvass thoronghly with the sturlent the relative merits of different types and methods of poultry keeping. from the points of view before indicated. His supervision might go the extent of passing judgment on any proposed purchase of breeding stock, chiclss or eggs.

$D$. The supervisor wonld not personally direet the daily rontine work of feeding and watering ponltry. His duties wonld consist of directing the thorough study of possible feeds and mixtures, their comparative enst and availability, and their suitability to the age, condition and purpose of the student's partienlar birds. For such supervision personal knowledge by the instrnctor of the cxact loome conditions would be necessary. 
The superrision of the practical home work of the boy or gint would naturally follow the settlement of such problems as these: -

A. How conld supervision and instruction be closely correlated?

$B$. How should the time of the instructor and of the pupil be apportioned between home and seliool duties?

(. That would be the maximum raclius, from the school building as a center, of effective supervision?

D. What methods might be employed for securing and holding the co-operation of the parent and the community?

$E$. By what means might satisfactory standards in the practical work of the student be maintained?

Thus far we have discussed the duties and responsibilities of the special instructor or supervisor of agriculture in the field of direction of the boy's projects on the home farm.

The instructor might undertalie to give help to others than those connected with his school. There are not wanting those who believe that such an agrienltural instructor attached to a regnlar bigh school might render valuable service to the community in which he was employed, in what might be termed the field of suggestion. Considering the previons training and experience required of this instructor, he should be a man well prepared to be of wide assistance in a farming community as an advisor in emergencies which called for special knowledge and skill. If met by a problem with which he conld not cope maided, - and there might he many snch problems, - he wonld know the best men. hooks and bulletins for consultation in such emergencies. Such problems might arise from attacks upon crops by injurions insects or by fungous diseases.

The friendly advice which the agricultural instruetor might give need not mean a meddlesome attitude on his part. His suggestions would not be given sare when requested, or when it was erident that they would be welcome.

The ficld of suggestion. would naturally begin with farms represented in the school by students. The instruetor would of course stand rearly to give the parents any advice of which he might be capalile, or to get for them, or instruct them low to get, any information which they might need or desire. With the 
gradual extension of his knowledge to the other farms of the community, he might be expected to stand ready in a similar manner to be of assistance to the owners of those farms.

3. The boy and his projects form a natural connecting link between the farmer and his farm, on one hand, and the sehool and its instructor, on the other. It the farm, the pupil deals with the practical aspects of his projects; and at the school, with their scientific aspects. The foregoing cliceussion has been deroted rhiefly to the practical aspects of the proposed project method of instruction. The present section lays strongest emphasis on the related study essential for the sucessful carrying out of a particular project.

Details of a Project Suitable for Third or Fourth I Iear Instuction. - Earlier in this chapter a project was dealt with which might, for the most part, be sucecssfully carried out by a first or second year student. For the present discussion a project has been selected which would require considerable maturity of age, strength and training for its successful accomplishment. It is true that simpler problems in potato growing have beu successfully carried out by elementary school pupils; but eren al glance orer the elements which enter into the project now to he outlined will show that problems altogether too rerions to be comprehended or mondertiken by the younger pupil are here involved.

It is to he mulcristood, of comrse, that the following project is but one of many which might be selecterl.

(1) Major Project. - It is assumed that the boy has chosen for his major project the development of a method for increasing the profit from the potato crop customarily grown on the bome falm. It is further assumed that 5 acres of potatoes are generally grown; that this year the crop is to be grown on (lovere sind; that the ramicty of potatoes to be grown has been chosen by the father; and that the boy's father is willing that his boy shall have complete control of a given number of rows of the 5-acre field, and shall be furnished the necessary tools and materials for his project.

(2) Hinor projects necessary for carrying ont the above major project might thon be as follows:- 
1. Insuring the most abundant crop by:-

a. A Proper Seed Bed. - The related study here would involve knowledge of: -

(a) Conditions of soil, air, texture, temperature and moisture most farorable to the growth of the potato plant, including methods of reducing an undesirable amount of "free" water, of avoiding too great dilntion of plant food, and of securing a desirable amount of "film" water.

(b) Methods of meparing the seed bed, inchuling the eomparative adrantages of fall and spring plowing, and the best treatment of the land in the spring after plowing and prior to planting.

b. Proper Fertitizing. - The related study here would include knowledge of: -

(a) Chemical composition of the potato plant, its osmotie and digestive processes, and the quantity of arailable fertilizing materials it is capable of assimilating.

(b) Complete fertilizers for the production of potatoes, including analyses of standard fertilizers, and the plant-fuod values for potato growing of chemieals and mixtures offered for purchase.

(c) Comparative desirability of muriate and sulphate of potash for producing a crop to be disposed of in an immature state as new potatoes, or for produeing a crop of late potatues to be disposed of for winter" use; and the extent to which the "mealy" charaeter" of the mature erop should be the determining faetor in chonsing between these two kinds of potasl.

(d) Clover sod as a factor in determining the proportion of nitrogen to be supplied.

(e) Best formula for a complete fertilizer for this particular crop, taking into account the potato plant, the previons crops and their fertilizer treatment in the system of crop rotation followed on the home farm, the present soil eonditions and the purpose of the crop.

(f) Most liberal amount of fertilizer warranted for use in growing this particular erop, in view of the known eondition of the land and the assimilative powers of the potato plant; and the saving in cost by home mixing of the supply to be used.

c. Lsing the Best Seed. - The related study here wonld include knowledge of:- 
(a) Botanical characteristics of the potato plant; the difference between a seed and a tuber; and potato improvement by various metlods and conditions of jropragation. taking into account tendencies of the putato plant to "rariation" and to "mixing in the hill."

(b) Importance of planting "scel" selecter in the field from the best-yielding lills, rather than seer selected from the bin merely by size of tuber's.

(r) Advantage of nsing polatoes for plonting which have been properly storm. am the eflects of freezing and sprouting in the cellar.

(d) Conditions under which it may be desirable to spront potatoes to be nsed for planting, in a warm, welllighted romm, - the temurentule, the tine and the care in handling required for surh spronting.

(e) Size of piece and number of eyes to the jiere, as imfortant factors in stanting the crop and in the quantity of its yield.

a. Proper Jlonting. - The related study here would inchude knowledge of:- -

(a) Botanical and chemical characteristics of the putato plant, as to its feeding habits, the growth of the inbers, and the effect on the tuluers as food products of exjosme to the sun during their growth.

(b) Distances between rows, and between seed pieces in the row.

(c) Deputh of planting. in its relation to ] rotection of the tubers from the sun, shiclding the eron from possible rot-producing barteria and surores, and subsernent cultivation, whether by the "level" or by the "litl " method.

(d) Pest time for jlanting, whether for "early" or for "late" potatoes.

e. Proper S srayinn. - The related study here would include knowleitge of: -

(a) Botanical chararteristies of the potato plant, particularly the relation of health and lnxuriance of foliage to tuber production.

(b) Insect enenies of the protato plant, and their entomological characteristies, snch as their methods of propagation and their feeding labits.

(c) Depredations of inserts, and their possible relation to attacks npon the potato plant by plant diseases. 
(d) Paris green: its chemieal composition: its protective action against the insect enemies of the potato plant; dangers attendant upon its nse; its possible combination with Bordeaux mixture; and the best formula, method of preparation and periods for its application.

f. Proper Cultivation. - The related study here would include knowledge of:-

(a) Physical characteristies of the suil, particularly the capillary movement of water to the surface of the soil, and exhaustion of soil moisture by evaporation.

(b) Surface conditions most favorable for receiving rain water without washing, puddling or subsequent baking.

(c) Value of a "soil mulch," and the most desirable method and frequency of cultivation for maintaining such a mulch.

(d) Comparative cost and advantages of "level " and "hill " cultivation, and reasons for the choice of the larticular method to be followed in cultivating the present crop.

$B$. Insuring the cleanest erop by:-

a. Dipping the "seed" potatoes in a formalin solution. The re-

lated study here would involve knowledge of:-

(a) Plant parasites which produce "scabby" potatoes, and

the biological conditions farorable and antagonistic to their growth.

(b) Formalin solution: its chemical constitution; its chemical action on these damaging potato larasites; and the proper formula and method for its use in protecting the potato crop.

b. Substitution of ehemical fertilizers for barnyard manme. The related study here would involve knowledge of:-

(a) Dangers of infection from the use of barnyard manure.

(b) Dangers of infection, if any, from the use of chemical fertilizers.

C. Insuring the soundest erop by spraying the potato plants with Bordeaux mixture. The related study here would involve knowledge of:-

a. Bacterial and fungons diseases to which the potato plant is subject; evidences of their presence; and whether or not they are preventable.

b. Bordeaux mixture: its chemical composition: its protective action against potato-plant diseases; and the best formula, method of preparation and periods of application for its use. 
D. Other minor mrojects would inchude the most profitable means and methods of harvesting, storing and warketing the crop. And other study related to these projects would inchde knowledge of potato implements and machines and their use; the comparative advantages of field pit and cellar for storage; prineiples and means of rentilation, and the temperature at which potatoes should be kept; near and more distant markets, and comparative transportation cost; prices and the probable tendeney of prices, in view of the press and gorermment reports of the potato crop for the State, New England, the country and the world.

Gencral Observations on Ficlated Study. ... The study related to the work of carrying out this potato project embraces, therefore, important matter from sereral seiences, including botany, chemistry, physies, entomology, bacterinlugy and plant patholngy. For the calculations, mathematics would be necessary; for keeping the accounts, bookkeeping would be required; for correct correspondence, there should be training in business English; consideration of transportation, markets and world production would involve knowlerlge of commercial and agricultural geography.

The project method of instruction on the side of related sturly, thus, it will be evident, must insure that the boy, in carrying out his projects, shall pass throngh a thorough-going educational process.

Good ritizenship. - It is proposed, furthermore, that the division of time, in carrying ont the school and home farm co-operative method of training, shall be about as follows: for the exccution of the projects, including work during racations anà other ont-of-school hours, to per ceut.; and for the related study, 30 per cent. The remaining 20 per cent. of the time of the boy is expected to be used for general enlture and good citizenship instruction, wherein systematic courses may be provided in such subjects as English, history, civics, eurrent events, mathematies and science.

Conclusion. - It is believed that the vocational education for farming proposed in this report, and embodying the project and part-time work method ontlined in the present chapter, will 
justify itself from every reasonable point of view, and that the system of agricultural schools which this report recommends will prove to possess undeniable merit as training schools, both for farming as a definite calling, and for intelligent and vigorous participation in the community life of the Commonwealth. 


\section{VI.}

THE PROBLEN OF SECURING COMPETENT INSTRUCTORS FOR A SYSTEM OF AGRICLLTURAL SCHOOLS

IN MASSACHUSETTS.

It wmld secus evirlent from the mecerling diconssion of the cintics and the opportmities of the instructor in agriculture that he is rrobaluly the most inrortant factor in the training of the youth for productive and profitable farming.

Whether he be employed in a separate agricultural school or as an expert in charge of an agrienltural department in a regular high school, the special iustructor or supervisor in agricultural eduration should bring to the work certain qualifications as to preparation, experience and personality.

IIe should be a craduate of an Agricultural College. - His preparation hould include gradnation from an agrienltural college or its equivalent. He should be familiar with and keep in tonch with the ofireers and the work of the Massachusetts Ampienltural Colloge and Experiment Station; and he should keep in fomch with the experiment stations in other States where work is bang done muder conditions similar to those in Mas-acturect?:

IIe shomld be familian with the work of the Tnited States Department of Ierivultme, su far as it is applinable to Massachusetts. Ho should he eapalile of keeping in toneh with new literature in pamplulet, periorlical and book forme, as it is issued, and to the extrut that it may he apmlicalile to his locality. He should be fomilial with the work of oremizations comcerned with rural puogress in Massachusetts, and apable of heartily co-operating with their officers.

His Erpericuce. - Prefruably, such a person mndertaking to prepare for agrienttural teaching in this Commonwealth should have heen reared on a Massachusetts farm, or on a farm wherp the arricultural operations would yiold experience of value for wrik in this State. Te should be a master of farming as a banticratt, and amply able to domonstrate the things which he undertook to teach; and lie slonld be familiar with, and 
be able to demonstrate the use of, the kinds of farm machinery which ean be economically used on a Massachusetts farm.

His Personality. - Since he must teach, such an instructor or supervisor must be effective in discipline; that is to say, in the handling of boys and girls. He nutst be prepared to meet people in his community pleasantly, and establish agreeable working relations with then. ITe must be prepared to maintain harmonious relations between his department and the other departments of the school, and be amenable to the authority of the officers responsible for the school which he scrves.

The duties of such a teacher of agriculture, attached to either a separate agrieultural school or an agricultural department in a regular high school, shunld in general be those which were indicated in the foregoing discussion of the activities in the field of part-time work in agriculture which he is to direet.

His school year might provide, at the discretion of the school authorities, for scrvice during the spring, summer and fall. months, giving him a vacation during the winter months; rather than for service during the fall, winter and spring, with summer months for vacation purposes. Suely a program would insure his services throughout the growing and harvesting seasons.

His absence during winter months would not seriously disturb the curriculum of the school; on the contrary, it would make room for the teaching of related subjects, inching manual training projects related to the farm, by other nembers of the staff to the lower classes, and might enable the higher classes to take winter short courses at the Agricultural College. Such a program would enable him to attend winter courses, and thus keep in touch with progress in agrieultural science, and become better acquainted with men engaged in research and experimental work.

The appointment and tenure of such a supervisor should be under the control of the local authorities, but subject to the approval of the State Bond. Where the superrisor is to serve a separate agricultural schnol, as at present constituted and administered under the Massachnsetts statutes, or an agricultural department in a regular high school, since his salary in either case is to be paid in part by the loeal eommunity and in part by the State, it would probably be advisable that he should be nom- 
inated by the loeal authorities and approved by the Bumed of Education; and in case of dismissal for cause, it would probably be best for such a dismissal to be approred by the Board.

Ordinarily, the yearly term of service for such a supervisor should be from the first day of April of any given year to the first day of April of the succeeding year. Dismissal for flagrant offense should, of course, be immediate and without notice.

The salary of such a supervisor is an important consideration. Experience seems to show that, in order to command the services of a man having the technical training, practical experience and personality called for in the above discussion of the necessary uualifications of a successful supervisor, salaries ranging from $\$ 1,000$ upwards must be paid.

In Ontario, where salaries for teachers and specialists of every type are on the whole less than in the States, six supervisors, with advisory and teaching duties, were engaged at the beginning of a co-operative scheme hetween the govermental agencies for agricultural letterment and the local school authorities. These supervisors were paid at the ontset, $\$ 1,000$ per year.

The Problem of Necessary Saluries is an. Economic One at Bnttom. - In order to attract to the work a supervisor of the type herein described, it will be necessary to make the compensation which he is to recoive as good as, or better than, that which is offered to him in competing lines of work.

By competing lines of work are meant occupations to which his interests, his talents and his preparation might attract him. 'The following positions at least lie within the possibilities of the desirable graduate of an acricultural college, and therefore coustitute competing lines of work: agricultural management work (for others or for himself) ; agricultural editorial work; agrioultural commeroial work; agricultural goremment work: agricultural research work; agricultural extension mork; agricultural teaching in colleges: agricultural teaching in high schools; acricultural teaching in agricultural schuols; asuicultural teaching in deparments in regnlar high schools; assistantships where valuable experiener under hislly speoialized superrision is to be had.

In a rely exhanstive stuly of the peparation and salnies of teachors giring instruction in agriculture in high schonds. Mr. 
C. H. Robison finds that the prevailing rate of pay received by desirable students in agricultural colleges immediately after graduation is $\$ 1,200 .{ }^{1}$

Such a superrisor must at the present time command a salary at least as high as, if not higher than, the arerage male teacher in ordinary high school work. Gradnates of classical colleges are much more abundant and available for teaching in secondary schools than are men qualified to teach agriculture.

The demands upon the teacher who is to serve as a superrisor of part-time agricultural work are so much more exacting than the demands upon the instructor in old-line training, that men possessing the requisite qualifications of personality and executive ability are at a preminm."

The salaries now paid to special teachers of agriculture of secondary grade are likewise significant. Mrr. Robison presents a table (No. 41) giving the salaries of 33 agriculturists engaging in school work in the past two years. Of these, the first 10 employed as assistants received less than $\$ 850: 23$ receired $\$ 900$ or more; 21 more than $\$ 1,000$; and 16 more than $\$ 1,200$.

The salaries now commanded by teachers giving special instruction in agriculture in public high schools and ofther public secondary schools would seem to indicate that the salary of the superrisor described herein must be not less than $\$ 1.000$, and must probably be more than that amount per ammum, if competent men are to be secured for the work.

\footnotetext{
1 In a thesis prepared for a doctor's degree at Columbia L'niversity, Mr. Rohison gives a list of 179 men graduating from agricultural colleges in the school year 1907-08. Tlis list shows that the salaries of over four-fifths of these men were rather evenly scattered between $\$ 750$ and $\$ 1,200$. The 21 higher-degrce men received an average of $\$ 1,20 \$ .33$, the prevailing rate being $\$ 1,200$. The general average of salaries for the 1907 group was $\$ 947.50$, and for the 1908 group $\$ 921.50$. The lowest salary reecived was $\$ 450$, and the highest $\$ 1,700$.

The significance of the above statistirs lies in these three considerations: (1) that the salaries tabulated were commanded practically on graduation day, and henee so not represent the added compensation which efficiency born of experience brings; (2) that the salaries tabulated include, possibly to an extent of more than a majority of the eases, the carnings after graduation of men not capable of acting as supervisors of agricultural training; (3) that the salaries were not coufined to men entering eelucational work.

2 The report of the National Educational Association, through its committec on salaries, tenures and pensions of public schon teachers in the Lnited States (1905), gives the average annual salary of male teachers other than principals in the secondary schools of Massachusetts outside of Boston as \$1,269; of male teachers and principals, \$1, 70 ; of male principals, $\$ 2,261$.
} 


\section{TII.}

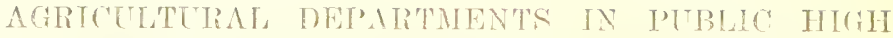 SCILOOLS TIIE PRINGIPAL PRESENT NLET \\ IN MASSACTITSET'S ARTICLL- TURAL EDECATION.}

The foregoing ahapters of this report have locen deroted largely to a descriprion of varions featues of the work of the

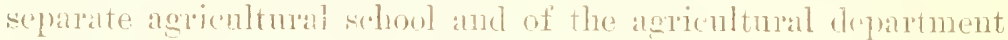
in the public ligh sthml, as lreing the two try es of training most desirable for a systen: of agrieultural culuation in this state. It is the purpure of the present chapter to disensis the probalble part

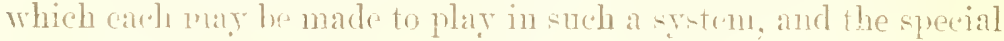
need of the angicultural department.

To-day in Maswachusetts there are three kinds of agrienltural education: ons for adults: another for whildren; and a third for purils of high school age.

Adult Agricullural Eduralimn. - Agrieultural edneation suitable for adultr was the fiust to receive attention, and has been most claborately dereloped. It now inclubles pullic exhibitions, lectures and remonstrations; hooks, perionlivals amol papers; field meeting held on farms. movalle selumb and hotter-farming trains; mormondence instruction and onllege rourses. Among the most active agente in promoting this rork for adults are the

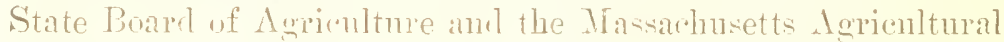
College.

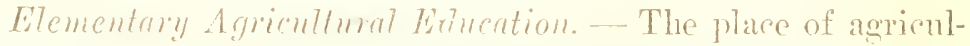
tme in the education of childien is dincmsed in chapter XI, where it is shom that promising hegimnings lave alpearly been male in teaching elementary sohnol children eertain rudiments of agricultural fart and pratice. The State normal schools and introrstal supurintendents of schouls have heen the most artive ageuts in this work. Valuable assistanoe has heen given by the Massachusetts Aquenltural College.

Secondary L Irimlluml Erluention. - Aquicultural education smitable for pupils of high sohol age is found in three forms: 
the private school, of which the Momnt Hermon School for Boys, with its electire courses in agrienture, is the most prominent example; the public high school, with some agrieultural instruction, of which there are said now to be twelve examples in this State; and the State-aided agricultural school of strictly rocational character, of which there are now two examples, the Suith's Agricultural School at Northampton, and the Montague Agricultural School at Montague.

The principa? piesent need, it is believed, is legislative provision of State aid for the establishment and maintenance, in existing high schools, of thorongh-gning vocational departments for the preparation of bovs, and perhaps some girls, for Massachusetts farming. In other chapters this report gives evidence that farming in this State offers a gond future to those who have been properly trained for engaging in it, and ontlines a method for making agrimltural eduration for those ahove fourteen years of age rocational! y effective.

The present law provides State aid for independent agricultural schools. This provision should be continned. But it is believed that this legislation is not adequate for meeting the immediate requirements of the State as a whole.

Only One Rural School has become an Agricultural School. Under the jresent law, only one rural school has heen renrganized, and converted into an agrienltural school, - the shool at Montague.

But One Scliool built, and that by Bequest. - Moreover, but one new agricultmial school has been establisherl, - the schoo! at Northampton. Without the Oliver Smith bequest, it is perfectly evident, to those who know the sitmation, that the city of Northampton would not now have that institution.

The school has drawn its sturlents from sixteen torms nutside of Northamptnn, as well as from the city itself. It is in reality a school for a considerable district, rather than for a single eity.

In the natural course of er'ents. Northampton, or any other city with a considerable industrial derelopment, would see itself well equipped for industrial training before it wonld, or perhaps could, qive a thought toward the establishment of an 
agricultural school for the benefit of its ontlying and more or less scattered farming population.

Six A gricultural Schools might be warranted. - There would undoubtedly be anple need of the ultimate establishment in this State of five or six independent agricultural schools.

Districts or Benefactors might build them. - If the burden of estahlishing such separate agricultural schools is too great to be assmmed single-handed by most towns, it is to be hoped that private philanthropy, seeing the need, may be indneed to supplement limited public resources.

$\Lambda$ group of towns may join in a district and find the undertaking quite within its grasp. In Essex County there is what appears to be a well-dereloped morement for the immediate establishment of such a school. By degrees the requisite number of separate schools for meeting the needs of the training such schools could so admirably give, may be secured.

The Slate should help maintain; it should not help construct or cquip. - It is plainly the estahlished policy of the State to aid in maintaining industrial and agricultural schools, but not in their construction or equipment. The State must not undertake more than it can carry out; and it is already evident that at no distant date the share of the State in meeting the cost of eren one-half of the maintenance charges of rocational education will hearily tax its eurrent resources.

Present Neci of Agricultural Departments, therefore, the Wore Trgent. - Since the demand for vocational agricultural training of secondary grade is pressing, and the establishment of agricultural schouls is likely to be long delayed, the need for agricultural derartments is seen to be the more urgent.

Fifly Departments for the Cost of Ten Schoots. - The cost of establishing a vocational agricultural department in a regular high school would be comparatively slight, - not a tithe of the cost of constructing and equipping an independent agricultural school. Mroreorer, fully fifty departments could be maintained for about what it would cost to maintain five large, well-equipped and effective agricultural schools. The provision of agricultural departments strongly commends itself, therefore, on the grounds of economy. 
Departments would reach the Greatest Number. - An agricultural department close at hand, which permitted the boy to live at home and help with the farm work morning and night and on Saturdays, would be most likely to appeal to parents who were in modest circumstances. Practically all parents, howerer well-to-do or howerer needy they may be, are rightly reluctant to have their children leave home at fourteen, or even at sixteen or seventeen zear's of age.

Many agrieultural drpartments widely distributed through the State would induce the attendance of the largest number of pupils, and thus provide a system of agricultural education suited to the needs of the greatest number of farm homes.

Departments would demonstrate. - Surrounded by farms, rocational agricultural departments in high schools would at once enlist the motor instincts and activities of the boys from these farms in the carrying out, simultaneously with their school instruction and as a vital part of it, of practical farming projects on their orm premises.

The best methods would be told and shown. And most boys, as well as most men, in agriculture as in all other productive pursuits, make their best progress by being told and shown, man to man, what to do, and why and when and how to do it.

General Schooling not Enongh. - Even in Massachusetts, where the school-going habit has been developed among the people at large to at least as favorable proportions as in most parts of the world. school instruction has had almost no direct bearing on the probable life work of a great number of boys and girls; and to-day, except in very few instances, it yields no practical knowledge or skill to those boys whose severest need is education for efficiency in the work and affairs of modern farming.

Book's and Bulletins are not Enough. - How many of the rank and file of busy farmers have had the time, the opportunity or the inclination for learning the alphabet of agricultural science, - that difficult alphabet, in which the most raluable bulletins and treatises on modern agriculture are written? The higher the aspirations of the men of agricultural knowledge, and the more commendable their accomplishments in the conquest of 
agricultural science, the more difficult of comprehension do their published works become in the hands of the man hard pressed by the claily aftairs of farming.

The need of the hour is the need of the teacher who can simplify language, and tell the boys who are to be farmers in a given town or district the practical bearing of the best research in agriculture on their problens; and who can show the boys, on their own farms and in the laboratory demonstrations at the school, the best methorls which are applicable to Miassachusetts conditions. It is to meet this need that a system of agricultural departments is proposed in this report.

The Farm is not Enongh. - It has been sail that "The worst thing about farming in New England is that almost any kind of farmer can get a living on almost any kind of farm." Productive farming - the firming for which additional rocational training is here proposed - is not eking out from the land the nakedest necessities of life. Productive farming is farming for the commmity, not merely for the individual; it is conomic farming, and as such contemplates profit in proportion to the service it renders the community, - in proportion to the quantity and the quality of the commonities put upon the market. Snch farming demants the higlust operative skill, the kcenest scientific insight and the broadest outlook over the wants and the welfare of the community. Many men on Massachusetts farms to-day are doing exactly this kind of productive farming. They have built up their alility through long years of experience. They would he the hest posible selmolmasters for their sons in this skillful work, this seicntifie insight and this brealth of outlook.

But, just as the lawyer who must practice law is generally mwilling to teach it, so the productive farner, who must meet the pressing demands of economic agricultural operations, and who in most cases must be at once the skilled operative, the scientific observer and the capable business manager, cannot stop to teach his boy the many things he ought to be taught in the years following his fourteenth birthday.

If this is true of the farmer of exceptional ability, it is eren more evident among farmers in general througlunt the Com- 
monwealth. There is no reflection in this observation on the "old stock" or on the immigrant. The statement is put forward as a matter of fact, and shows a condition which has grown, and must continue more and more to grow, ont of the axigencies of modern economic agriculture.

If the office alone is not enough as a training school for modern commerce, it becomes increasingly erident that, while the farm must have a necessary part in asricultural erlncation, as is shown in chapters IV. and $T$. of this report, it is not enongh for the training of the prospective productive farmer. The agricultural departments would mudertake to render a service to productive farming like that rendered the world of business by the public school department of comncree.

Open Doois of Opportunity. - MLr. D. J. Crosby, specialist in agricultural edueation of the Office of Experiment Stations, Washington, D. C., has written that he hopes to see secondary agricultural education thronghont the comtry "Open at both ends," - opm at the heginning, so that the farm boy can enter; and open at the end, so that those farm boys who desire to go on to higher agricultural training shall be able to do so.

The agricultural departments, as slown in another chapter of this report, would admit any farm boy who had reacher his funtcenth birthday, withont regard to whether or not be could pass entrance examinations for admission to high school, provided he conld demonstrate his ability to profit from the agricultural instruction offered. This would ripen the door for the boy who might not be "bookish," lnt who might be capable of making excellent progress in applied science as worked ont by the project. or part-time, mothod proposed in chapter $Y$. of this report.

Fuller opportunity, at the same time, would be afforded the hoy who might be both "bookish" and "practical," for" arlvancing in both agricultural and acalemic training. As stated in chapter V. 20 per cent. of the boy's time wonld be definitely reserved for broadly enltural education. If a boy who was training for farming valued graduation from an ever more strongly cultural course, one that perhaps even inchded Tatin or Greek, and if he were able to corer the ground re- 
quired for such graduation without detriment to the vocational training in his agricultural course, he, too, should find wide open before him a door of opportunity commensurate with his ambition and his natural powers.

Nore and more, agricultural science is bound to be recognized in units of crestit for meeting college entrance requirements; certainly for meeting the requirements for admission to colleges of agriculture.

It must be erident, in short, that the agricultural departments in high schools herein proposed would throw open to boys from the farms not limited opportunities only, but opportmities for the most adranced agricultural education of which they might be capable and to which they might aspire. The fact that firm footing for their fect would be found at the ontset through the immediate application of their science instruction in their home farm projects, would certainly be no detriment.

Lroidunce of Lndue Delay. -- The establishment of agricultural departments in existing high schools conld not be accomplished over night. Their snecess wonld depend upon picked men for teachers; and the selection of snch men, or their training, would require time and attention. Some time would be required, also, for enabling the local advisory committee in consultation with the State authorities to ontline the course of training best suited to meet the needs of the farm boys in any given locality. Certain special agricultural class-room facilities and equipment wonld require some time for preparation.

But the time necessary for the establishment of such departments would he comparatively brief. In one, two or three veal's it should he pussible to have a rasomahle number of such departments artively at work, and reaching most of the farm boys in this State who need this form of agricultural education.

Conclusion. - ('hief stress in this chapter has been laid on the newl of a grienltural departments in existing high schools. and the service they might he expected to render. Tt is recognized that a new and mutried methor of instruetion is proposed in this report. There have been certain approximations to both the separate agricultural school and the agricultural department 
in a high school, as here defined and discussed; but nowhere has there been the definite and studied employment of the project and part-time method of training here contemplated for use in both the agricultural school and the agricultural department.

While, therefore, it is believed that the system of agrieultural schools recommented in this report will prove to be an important contribution to the progress of education in this Commonwealth, it is believed, also, that the experimental character of the proposed system, particularly in matters relating to the agricultural department. should be distinctly recognized. To this end, accordingly, the appropriation for aiding such departments has been restricted to $\$ 10,000$ a year, - a sum sufficient to start a small number of such departments.

Intense interest in the proposed system exists among farmer's, business men and educators throughont the State with whom it has been discussed. Tnder the supervision of the Board of Education, the work could be subjected to the closest scrutiny, and would be undertaken with corresponding care. Departments need not be established excepting where conditions for their successful derelopment were believed to exist. Every possible assistance could be given those immediately responsible for putting into effect the method here proposed. If the results proved to be disappointing, the appropriation for departments should be discontinued. If the results here anticipated should he realized, the amnual appropriation could be increased and the system further extended whenever such action might be considered necessary or desirable. 


\section{VIII.}

POSSIBLE LOCATIONS FOR AGRICULTURAL SCHOOLS OR DEPARTALNTS.

Where shomld the schools and departments in a system of agricultural culucation for Massachnsetts be established?

Previonsty in this report it has been stated that the establishment of five, or possibly six, separate agricultural schools might be warranted in Massachnsetts. 'These might well be located at the most casily aceesible points in ach of six, readily separable, divi-inus of the state which furnish the lome markets for Massachuretts agricultural prochucts.

That thre are six such divisions has been shown by Secretary Ellsworth in his fortheming pamphlet, entitled "Massachusetts, her Agrienltural Resonres, Adrantages and Opportunities," to which refrence has been mate in chapter II. His prefininary statement concerning these divisions is as follows:-

The home markets for Massachusetts farm products are confined principally to the 33 cities. These rities, all containing more than 13,000 people, represent almost two-thiris of the total population of the State. The inlobitants thereof are wholly rependent upom the farmer for sustenance. The cities of the State lie in six groups, the locations of which, as previonsly intimated, were detemined largely by the existence of special industrial and commercial facilities.

1. Desirable Locations for Agricultural Schools. - If the six agricultural maket divisions of the State were to be followed, schools might be located in the divisions described by Secretary Ellsworth, as below shown, and for reasous based on the investigations leading to this report below given.

(1) "The most restem group," says Secretary Ellwworth, "is that comprising the cities of P'ittsfield and Nortlu Adams, having a combined population of 45,000 . These markets get all their dairy products and fruits and regetables in season from producers of northern Berkshire."

Pittsficld promises to be an excellent center, and the time secms opportune for the establishment there of a separate 
agricultural school. The formation of an agricultural fair association is under consideration by the Pittsfield Board of Trade, the local Grange and influential citizens. It has been suggested that the two projects might be worked ont together. Some of the fair buildings, which otherwise would be nnoceupied fully eleven months of the year, might be used for the school. Some of the school equipment and operations might contribute features of very great value for carrying out the educational purposes which the annual fairs would be intended to serve.

Pittsfield is a trade and transportation center for the towns of Lanesborongh, Dalton, Lenox, Lee, Cheshire, Berkshire and Hinsdale. This group of towns, with Pittsfield, has a total population estimated at 50,000. The population is said to be increasing at a rapid rate, and to be far outstripping the agricultural development of that section of the State.

(2) "The second group," as described by Secretary Ellsworth, "comprises Northampton, Holyoke, Chicopee and Springfield. These cities lie in the lower Comecticut River ralley. The last three named are in Hampden County, and are the most populous. The total population is 145,500 . This market group draws heavily upon the productivity of the Commecticut valley for 30 miles of its length and from the hills on the east and on the west. The prosperons market gardcners close to the city limits attest to the excellent marketing advantages of this region."

The Connerlicut Falley now supplied. - The Smith's Agxicultural Schonl and Northampton School of Industries now in operation at Northampton, and previonsly referred to in this report, is equipped for serving a large area in the Comecticut valley and on the neighboring hills. Students from 16 towns have been eurolled for work in this school, and with but few exceptions have been able to reside at home, - due to the excellence of Northampton as a transportation center.

(8) "A third group" is that made up, according to the analysis of Secretary Ellsworth, "of Worcester, Fitchbure and Marlborough. The former is by sereral thourands the largest city, and no mean percentage of its people are partially self-snstaining. The combined population is 163,500. The supply for these markets comes mostly from the southern and eastern parts of 
Worcester County. Railroads enter the cities of this group from twelve different directions direct from the producing sections."

Worcester has been discussed separately in chapter IX. of this report as a most desirable center for an agricultural school. The resources of the eity are rich, the agricultural production of its outlying sections is large, the population conditions are adequate, its transportation facilities are excellent, and the conterprise of its local agricultural and horticultural oreanizations is noteworthy. Few communities could offor conditions more promising for the successful establishment and maintenance of such a school than those which would be found in Woreester.

(4) "Inother group of rities," indieated by Secretary Ellsworth, "lie alnng the Merrimae River in nothern Essex County. Jowdl, Jamence, IIaverhill and Newburyport make up this sromp, and afford markets for that section of the State. The railuads are numerous, but do not enter into the morement of protuce to these markets to any extent, most of it being drawn orel the excollent macalam roarls with which this section is admirably smplien. Clounster, on Cape Ann, is a city of mure than 25,000 people, which requires its portion of soil products. It is known best as a port and market for the fishing industry."

In Essex Comuty several locations have been suggested, and it appears that pullic sentiment has been thoronghly aroused, hy the Associated Boarts of Trade and other organizations throughout the entire county, in faror of the early establishment of one agricultural school, and ultimately of at least two such schools.

1. Danvers has heen suggested as a center for such a school. The section about Danvers mar be described as pre-eminently deroted to market gardening. The distriet served might well inchule Lymn, Marblichearl, Salem, Peahorly, Beverly and Danrers itself. Tt is urged that dav students living at home conld attend selool at this renter from points as far north as Topsfichd. Boxford, North Indover and even IIaverhill, more cheaply than they could buard, and have margins of time for testing daily at lome the teachings of the sehool. 
B. The Merrimuc valley. it has berm urged, would furnish a desirable center. Agrienlture in the Merrimac ralley section is rich and varied. It embraces general farming; fruit growing, including peaches and strawberries; and market gardening. The district served might well inchude Andover, North Andover. Boxford, Georgetown, Groveland, Lawrence, Methuen and Maverhill. Towns even as distant as Danrers, Topsfield. Newburrport and Salisbury would not, it is beliered, be too far away for the attendance of day students.

C. Topsficld also has been suggested as a center, owing to the gift of a valuable farm in that town to the Essex 1 grienltural Society for edncational purposes. This farm would offer admirable field facilities for purposes of instruction. The soil, especially in its diversified topographical contonrs, is typical of the farming land in the immediately surrounding section.

Against this point as a center for an agricultural school has been urged difficulty of aceess. Topsfield has no electrie "ar' serrice, and is crossed by but a single steam railway line. It might be that an enrollment of day students could not be assured sufficient to warrant its selection as a center.

D. Bererly, or some other spot on the Torth Shore, has been suggested as a center. It has heen urged that an agricultural school might be established and equipped by subscriptions from wealthy residents, and that a district for its maintenance might well be made up of Bererly, Tenham, Hamilton, Essex, Manchester, Gloncester, Rockport and perhaps Ipswich. Such a school, it is ureed, should provide instruction in general farming. and should also give particular attention to landscape gardening.

It is said that the North Shore country seats demand much skilled agricultural and horticultural work of all kinds, and that for meeting this demand the establishment and maintenance by the means above named of a somewhat specialized agricultural school would be warranted. There appears to be no little merit in this proposal, and the transportation ennveniences would make a school in this locality accessihle to a large district.

(5) "The cities of the fifth group." as deserihed by Secretary Ellsworth, "are rather widely separated, but, as they are responsible for considerable agricultural activity of a particular see- 
tion, they may be taken as constituting a market for that section. These cities are Brockton in northwestern Plymonth, Taunton, Fall River and New Bedford in Bristol, and Woonsocket, Pawtucket, Central Falls and Providence in the State of Rhode Island. The combined population of these cities in 1905 was 500,000, which was nearly ats great as that of Boston.

"This, however, cannot be taken as a true measure of the market for Mrssachusetts farmers of this section, since the Rhode Lsland market wet the larger portion of their produce from Rhode Tsland soil. The Massachusetts cities named above have a population nearly crual to the Rhorle Tsland cities, and, with the exception, perhaps, of Fall River, get all their native food stuffa from IIasaidnusetts farms. Transportation facilities are excellent, no less than thirty lines of railpoals entering the cities of the gromp. Probably most of the garden truck is taken to market over the highways."

The Faune Demonstration. Farm at Sundwish might serve as a molens for a separate agricultural school for the Cape Corl section. The real astate of the Fannce Temonstration Farm, when hequeathed in 1909 for its present ure, eonsisted of two

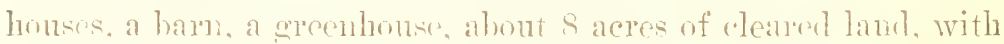
50 acres of worklland arljoining and other woodland at a dis1ance. With this real estate there alon was recerverl a fund of abont $\$ 20,000$. The whole property was left as a momorial to Dr. Tiwhert II. Fannee, who had dies sumdenly the year hefore, by bis mother, in the hands of four of her personal frients as trustees, with wide liseretionary jowers, hut with her wish well understrod that the estate was to be nsed to cncourage Cape Cod agrienlture. T'ononstration work in fruit and regetable growing and in prultry farming has been enerectically undertaken. This establishment was described very fully by the "Boston Ileralel" of Nor. 2\%, 1910, in an illustrated article, entitled "The Farm withont Frills."

The emulitions at Sandwich are so rlosely typieal of the Cape as a whule, and transportation facilitirs are such, that Samrlwich naturally sugousts itself as a iesirable center for an agricultural schonl. Asuicultural production in that section has lieen sorely neglected, producta which might well he growu at home being bronght in for supplying local necds from the Boston markets. 
The importance of Sandwich as a center is expected to be greatly enhanced by the completion of the new Cape Cod Canal.

The people of the community, particularly the school boy. have responded to the influence of the Fannce Lenionstration Farm. The superintendent of the farm, as this report is being written, is instructing special classes of high school students who are desirons of the training this farm and its manager are prepared to provicle.

(6) "The sixth group," discnssion of which Secretary Elsworth deferred until the last, because of its magnitude, is that which, he says, "for present purposes may be called the Boston market. Fifteen cities and about as many large towns may be included in this group. It has its center at Fanenil Hall, and radiates for 10 miles nortli, sonth and west. Within the ciremmference of this territory there dwell more than one-third of all the people in the Commontrealth. Well may Bostom be termed "the Hub;' it is truly the center of this cnomous market."

The Suburls of Boston. - It is well known that the greenhonse and market-garden interests in the vicinity of Boston have reacherl enomons derchonent, and it has been suggester that a special schuol for training prorlucers of market-garden and greenhonse crops might well be established in one of the suburbs of this city.

Such a school might matcrially differ in its course of study from the other agricultural schools, and form a rery important part of a system of agricultural education for the State. Students who desired to specialize in these branches of agricultural production might, at the end of the first two or three years in any of the other agricultural schools or agricultural departments, possible locations for which are hereafter discussed, he transferred to this school for a one-sear or two-ycars finishing course; that is to say, snch a school might well be organized for providing a short course of highly specialized instruction for hoys of sixteen or more years of age.

2. Possible Locations for A gricultural De partments in Existing IIigh Schools. - Local conditions should be strong factors in determining whether or not the establishment of an agrienltural department would be advisable at any given point.

There is throughout the State a rery general cxcellence of 
transportation facilities. When, for example, possible locations for the proposcd Massachnsetts College centers were being selceted, it was found that 30 such centers could be so placed that 92 per cent. of the sehool population of the State would live within the range of a five-cent fare by steam or trolley from these centers, and that six per cent. more womld live within the range of a ten-eent fare. Transportation facilities are likely to be found favorable at most points which might be suggested.

In choosing locations for agricultural departments in high schools, some accomnt should mudoubterly be taken of the tendency of agriculture to derelop more strongly with reference to local market demants than with reference to any local peculiaritice of soil or traditional production, - a temelency which has heen referred to by Seeretary Ellsworth. Strong or distinctive home-market centers for agricultural products might well, as in the cases of the agricultmral schools, furmish the most desirable locations for agricultmal departments.

Following are centers — but not always market centers which have been suggested as likely to be found desirable for the location of rocational agrienltural departments in existing high sehools: -

(1) Crreat Barrington might be found desirable as a center, so far as the farming interests and transportation facilities are concerned. Farmers conversant with Great Barrington conditions have estimated that an ammal enrollnent of 20 farm boys conld be assured, if such a department shomlil be established, with an nltimate enrollment of probably not fewer than 50 . The suromding towns have no manufacturing, but contain many estates of summer resilents and many typieal western Massachusetts farm. These trows now seml a number of tuition students to the Great Barringtom high schoul.

An agricultural department at this center might be found rery curvicealile, therefore, to a considerable surrounding territory, as well as to Great Barrington itself. Instances are given of sturlents, living at home, but attending solool in Pittsfield from points as far south as Stockbridge. The distance from Stockhridge to Pittsfield is of comrse much greater than the ristanee from Stockbridge to Great Barrington. It has been 
unged that. with an agricultural school at Pittsfield and an agricultural department at Great Barrington, the Berkshire section of the State would be well supplied with means for the agrienltural edueation of boys fourtem or more years of age.

(2) Il'est springfield has been suggested as a farorable spot for a strong agricultural department course in market garlening as well as in general agriculture. There would be abundance of illustrative work going on within easy reach, and the transportation facilities for day students would be all that could he desired.

(3) Patmer might be another desirable center. This is a town of ahout 8,000 inhabitants, and is made up of several villages. It is an important transportation center, being intersected by several steam railway lines and served by numerons electric car lines radiating from Palmer village as a center. A large farming area might thus be readily accommodated.

Across the river from the village is a rery large State institution, with extensive farms and varied farming operations. Inch help is there employed, and practical work might there he had by boys from village homes who desired to be trained for farm life and work. The superintendent of this institution has expressed great interest in the possible establishment of an agricultural department in the Pahmer high sehool, and might be relied upon to do everything possible for enhancing the value of its practical instruction.

Palmer has three outlying manufacturing villages, in each of which the mill property includes farming land. The agents of the mills have expressed considerable interest in the possibility of an agricultural department in the Palmer high school. One of them would contribute forestry demonstration work; the others would render any assistance which might be foumd prarticahle.

(4) Sandwich, if the Faunce Demonstration Farm were not developed into a separate agricultural school, wonld be admirably suited for an agricultural department. The farm would provide excellent means for demonstration and practice work at the school, since the farm is but a few steps from the high school building. 
(5) Kingston wonld lie another farorable point. Thongh Kingston itsclf might not assure an enrollment sufficient to warrant the establishment of such a department at the local high school, the transportation facilities are such that a department located at Kingston might serve a considerable territory. including the towns of Plymouth, Carrer, Plymptom, Halifax, Silver Lake and Duxbury.

Kingston no kubt has been suggested owing to the kcen local interest in agricultural improrement which las alreacly been aromect. There is a molel farm operated by a private uwner in the ricinity of the high seluoul, which wonld afford proper lemonstration facilities.

(6) Eyfichl las been suggested as a gool conter for an agrirnltural drourtunent. T)mmer deadrmy is locatod in this town, and owns a farm fairly typlical of the land in this section. It bas been suggested that the town anthoritics, acting with the ofticers of Dummer Academy, misht utilize the academy fam and a portion of the academy buildines for the establishment of such a department. Byfield has dectric car service as well as steam, and day students from Newhory, Georactom, Towbley and Ipswich might there be accommodater.

(7) Walpole is another lowation which las heen snowe ted for a department. Three rery intrestine tarms, one a purely inrosment proposition, one where clean milk is produced muler exreptionally gool conditions, and another whore an mulertaking is moler way for dereloning a farm which shall grow all its own grain as well as romohage, would afford very musmal illustrative farcilities. not tom far distant. Iralpule has both stran and dectric railway seprice, and a department in the Walpole hish school might well serve a comsiderable smrountinsweserion.

(S) J'etersham is another center which has been sngagstert.

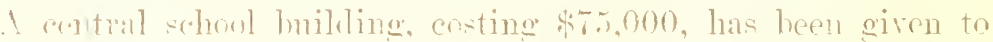
the town. In this are acommolated all of the orades of the lucal subols, inchuding the high schont. In oritur that agricultural instruction might be given, a small greenlouse was crectriel and a small trict of land for ont-door work was provirlect. The school has already taken for its name the "Peterslam In'ricultmal High Sohool." 
3. Procedure for choosing Localions for Tocational Agricullural Schools. - Other desirable locations for both agricultural schools and agricultural departments will undonbtedly be bronght to riew. The lists above given simply make record of those possible center's which hare most readily singled themselves out, owing to certain obrious, and, as a rule, peenliarly arrantageons, local conditions.

No serions work conld be expected of any commmity in the direction of a definite canvass of its specifie requirements and possibilities, in the absence of legislation fixing the general policy of the State as to the desirability of establishing a system of agricultural schools thronghont the Conmonwealth. Such legislation might be expected to follow the submission of this report. For these conducting the prelininary investigations leading to this leport to have ureerl such canvasses wonld have been to enter the field of propaganda, - a fielil construed to he foreign to the present purpose.

In the exent of favorable action by the Legislature on the establishment of the system of rocational agrienltural schools recommended in this report, the procedure for choosing a location for a school or a department would probably he somewhat as follows:-

(1) A local committee interested in the subject might petition the Board of Education for a conference. Such a committee might be the regular school conmittee, acting throngh the superintendent of schools: or it might be a group of interester citizens, such as members of a srange or of a board of trade.

(2) The conference might be expected to result (it) in a careful canvass of the local farming conditions and the local market demands for agricultural prodicts; and $(b)$ in the tentative formulation of a conrse of traiming which appenrecl to be suited to the farming needs of the particular locality.

(3) It might then be advisahle that a careful censuse of the local school population should be marle, for the purpose of cotimating the number of boys just approaching the fourternth birthday or just past it. who would enroll in a sehool which should proride such a course of training as that tentatively formulaterl.

(t) With the list of prospectire sturtents in hand, the next 
step would prothalily be to seemre asturance from the parents of thus sturlouts of willingmess to co-oprerate heartily with the -choul in carrying ont the programme of part-time work, which is bedireal to be esential to the proper conduct of the propused trpe of anpoultural edncation.

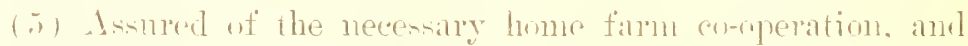
an arequate emollment, the next natmal steps womld be: (a)

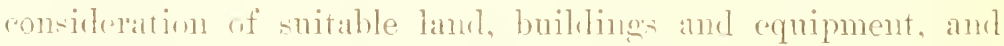
their probable cost: $(b)$ the availability of snitable teachers, anul theip jobluble ast: and (o) the probablo cost of maintenance, other lhan the "xpense for offiress of instruction and alministration.

If a department in a high selonot were contemplated, the alvere

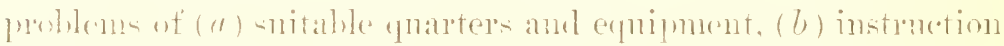
and (e) miscellanems necessary mainteminue cost would he much simplifienl. The attitude of the local high school officers and trablers womlel previously have been asertained when the

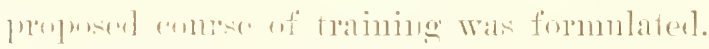

(i) With all tho needs definituly knom, ways and means of [moviling fomls am] election or anpointment of official local

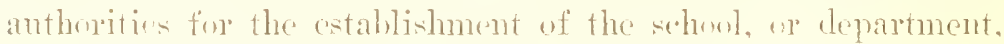
womkl le tla urst natmal objects of attention.

1. Artion might he sueedr and the ponlems simple, if the

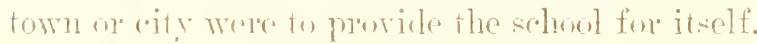

B. Artiom might he suw and the problems mone aliticnlt, if the selhenl were to he provided hy a distriet of sereral ritios an tombns, or aitios and toryms.

C. All womlel mont reatily he aromuplished, if a private

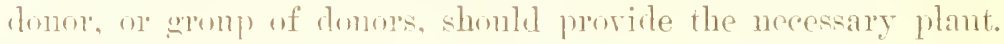

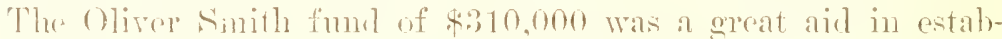
lishine the acricultural school at Northampton; as was the Fanner bequent in estallishing the Fanuce Demonstuation Farm at Santwirll, and the resultant agrienttual instruction durjug bat of the var inow given high school sturtents in that town.

In arlilifon to the snogestert North shore sohool which it is thomght might he built and equipped hy private donors, it is mulerstmul that another project, somewhat of the Sandwich type. is likely to be provided for at an early ute hy private gift. 
Few bencfactions are likely to be more permanently useful than modest gifts and bequests of the Fannee type, which would provide desirable school equipment at many points for the more practical elements of the agrienltural education of the boys and girls who expect to live their lives and do their work on Massachusetts farms. If large discretionary power's were ludged with the trustees, local sehool authorities or the Boarl of Edueation, every interest of future progress wonld be served, as well as the obrious preseut need, by such benefactions.

(7) Finally, it may be said that, since the schools proposer would receive State aid for their maintenance. subject to apfroral by the Board of Edueation, the Commiscioner of Edueation and those representing him might be expected to render. at all stages of the proceedings, erery possible assistance to any local community which desired to establish the trues of arienltural education propused by this report. 
IX.

REA TMIENDATION WITH REGARD TO AGRICULTERAL EDECATION FOR WOREESTER.

In aceordance with the provisions of chapter $10 \mathrm{~s}$ of the Resolves of 1910 , the investigation learling to this report considcreal the "praticalility and desirability of establishing a farm school in the city of Worcester in which instruction may le wiven, free, in the raising of froits, veretables, fiowers, wrains, plants and frees, and in the are of domestie animals, and in whirh sintilar instruetion snitable to their years may he given 10, rhithlec11."

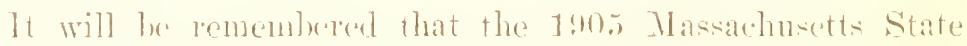

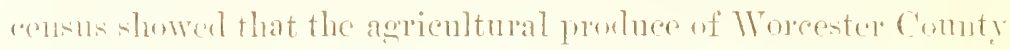
was lepented as $\$ 14,279,000$, and of the city of Wolcestop alome

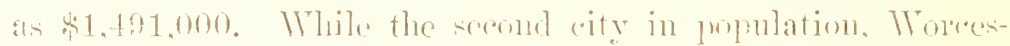

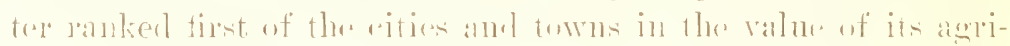

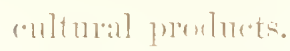

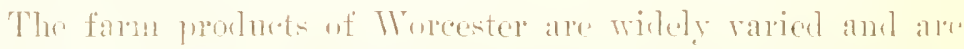
walily maktod. The lone sopes which chatracterize the ontlyine land are fomd to lo remarkably farmable for fruit,

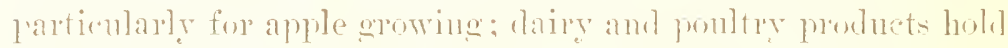

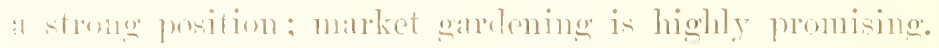

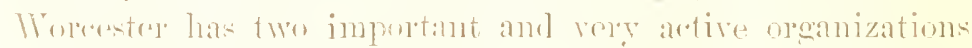

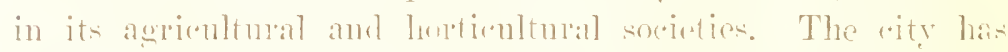
mate a must commendalle beximning in trade solool work, and the romuliug ont of its srstem of rowational traiumg of scemulary grade might well take the form of a strumg separate

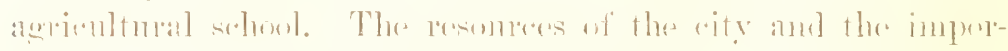
tane of its farming interests wolld tully wardant the establishuent and maintenane of sncls a sehool.

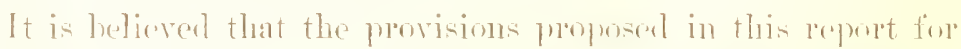
merting the neals of the State at larefe for a system of roratimal acricultural edueation of secondary grate womld meet the requirements of Woreester, and that, therefore, special les-

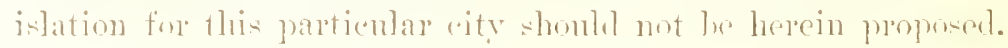


X.

AGRICTLTLRE AS A PHASE OF LIBERAL EDUCATHON $1 \mathrm{~N}$ THE HIGH SCHOOHS OF MASSACHUSET'S.

It is appropriate that something shonld be said in this report with respect to the stuly of agriculture as a part of the program of the so-called liberal education, to which onr schoul system has heen for the must part deroterl.

There is an active novement in secomlary education looking to more effective organization of subjeet matter and nether for the purposes of liberal or enltural exlucation. In this morement it is natural that many persons shonld look upon agriculture as a promining and attractive field of secomblary schend stuly, especially for rural high schools. For this purpos it presents sereral aspects.

1. Igricultural Lands and People. - In the econonic life of all the centuries, agriculture has played an important part. The control of the fertile lands in the great valleys and plains has matc and mmade nations. Political organization has in all times been greatly affected by the ownership of land and liy the kind of agrienlture practiced.

In onr own century territorial division of labor plays an inportant part, with the result that one kind of farm industry monopolizes the lower half of the Mismissippi valley; anther,

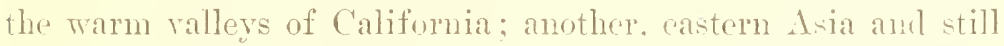
another, the pliains of Canada.

To the student of the play of social forces, the distribution of population along agricultural lines is a fascinating theme. One can read with intense interest of the effects of ocenpations on the social life of the peoples of the prairies and the tropise. of the inhabitants of the great steppes of Rinssia and of the small enltivators of France and Italy.

?. Igricultural Scionce and Incention. - Experially interr.sting as themes for study are the transitions which the nineteenth and twentieth centuries have hronght into agrienlture. The inrentions of science and the evolution of machinerer, subtituting animal strength and natural fores for human brawn 
and sinew, luave increased agricultural production, have extemded human prosperity, and lave made the farm a field wherein seientifie knowledge finds abumlant apnlication.

Many a seientist has, within the last halte-entury, enriched lumanity hy lis contributions to eftective farm moduction. 'The work of on own mational governunent in agrienttural research and in spreading a linowlerlge of approved methouls constitutes a most rheering sign of govermmental actiritr.

It is evilent that, along these and allicel lines, it is posible tr. build np a field of study which as a part of liberal elucation would easily rank with certain subjects now tanght with

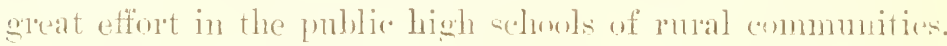

3. Science Laboratory Illustmions from Igriculture. Agrenlture must increasingly le comsidered as a fir ld of applien s.ience. Phrsical and commercial grography, botany, zorilogry, lacterinlogy, phyiology, chemistry, ecomomics, have mumemo inportant applirations in agricultule, and many of these applications are so concrete and simple as to constitute excellent labaratory illustrations.

It is not strange that seekers for more satisfactory methols

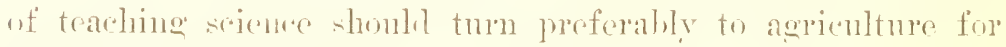
slogestion and nuaterial. It has heomese nowe and more crident that science cammot be very effectively taught to semolary students stricty in its "pure" form. Children of the adolesrent stage of derelopment apparently resonel nole satisfaretorily tw that seiene teaching which begins with applications and (o)nerete cases, and then merges into generalizations, principles and laws. We knew that this is the historie order in the evolution of scientific knowlectge, and it is not impmolnble that in the main the perlagogice onder must follow the historic order.

In the high nolool attempts are heing mate in many plares to

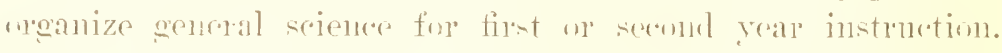
This contes antists in some instances merely of topies selected

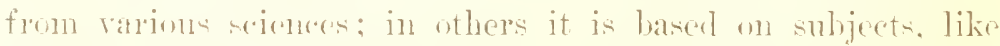
plexical sonerajhy, which involre principles and applirations from man! se.icneos.

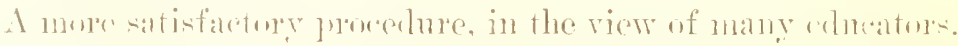
will be to take the suljucot of agrionlture, abommding in rlirest 
and practical applieations from many seientific fields, and to organize a course of instmetion in which the pupil will arlvance from concrete experience to an appreciation of underlying scientific principles, and also at every step become cognizant of the real significance of the subject in promoting personal and social well-being. In able presentation of secondary school science of this kind recently appeared from the Lnited States I)epartnucnt of Agrienlture (Experiment Station Record, September. $1910)$.

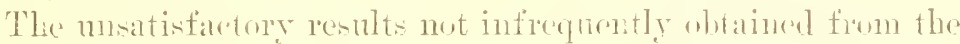
study of abstract mathematics and formalized physics seem to justify the betief that agriculture can be nsed to adrantage as a means of approach to science, in a scheme for libral exhcation in sceondary schools.

4. Igriculture and Wholesome Living. - The conception of modern liberal elucation inolves to an increasing extent a study of social conditions and of the factors that make for whils some personal and community living.

We are in the midst of a reaction against the morement to the city, and sturlents of social economy are beconing more and more convinced that the derelopment of sound citizenship, as well as of sonid phrsique, as a nation, is depentent on a large agricultural population.

The study of agriculture as a field of human activity involves constant reference to the social characterintics of rumal anmunities, and to the means for the better development of dewirable pursuits. One important question relates to the bearing on phrsical health of rural life and its oceupations.

5. Agriculture and the Educational. Tatues of Concrete Experience. - Nodern education is developing a wider and hetter fischologieal outlook. Erturation in the past has been identified with instruction given in sehools; and school training has, owing to the foree of ciremmstanes, heen an education by means of books and writing. modified in recent years by more or los. laboratory experience. Mtodern pedagngy, wh the other hant. maintains that arademic teathing can he effective only as it builds on a basis of concrete experience, obtained by a thumgh antart with the realities of life. 
Inefore the develonment of morlem rities and the resulting industrial conditions, a lare majority of growing buys and ginds lad alumelant apportunity to share in prodnctive ocempations, to participate in the natural sports of childhood and to acquise inchustrial experienue, simply throngh enutact with their environment. It seens to be biologically true that this basal experience is neecsary, as antecerent to the form of coluration we call atcalemir.

6. Some Igrienllure almost Indispensable to Sound Eiluerefion. - Manual trining and laburatory worts in science have

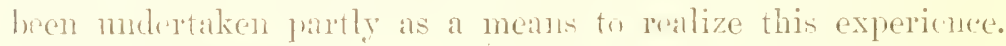

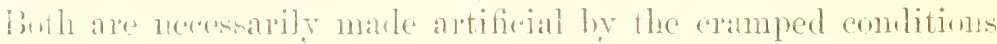
moler whinh they must be comblueted. Agrionlture offers a peonliar opportunity for a more extemled and satisfying field, wherein this basal experione may he aropured.

It munt he moted that this aromment has no reference to vorattional training. In fact, it might be meged from the standpoint of liberal eduration that persons destined for the profesions and harmed callings stand in greatest med in their earlier vears of hroal experience with the soil, with romestic animals and will the conditions of prodnction in nature. In many commumitics a certain mumber of hom per woek deroted to agricultural

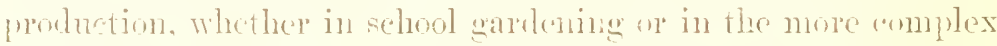

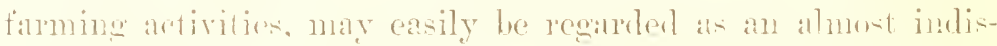

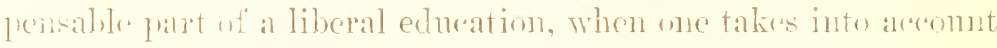
tho conditions involved in modom lifir.

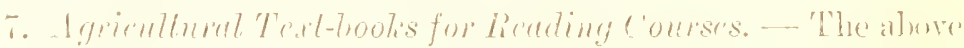
ronsiderations serve to lefine to some extent the pant which

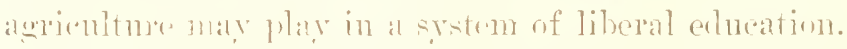

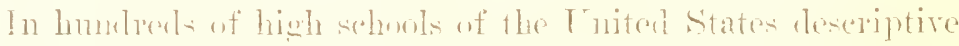

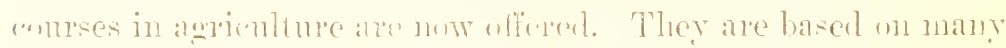

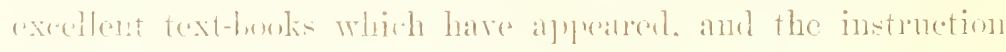

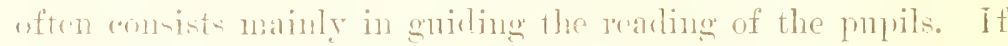
the teacher himede be interested in the larger ecomonic and

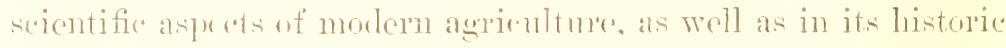
arolution, he an make the subjert one of intense interent. arem withont lahoratory domosstrations or firld experience.

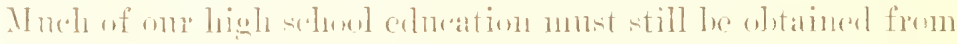

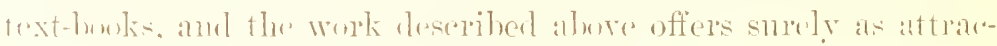


tive a subject of stndy as ancient histriry, text-bonk science as sometimes still taught, or mathematics.

S. Igricultural Mamuals for Science Laboratorics. - Many schools are ambitions to go farther. and in a somewhat different direction. Ther prefer not to treat agrienlture in its broad gengraphical or historic aspects, but to nse it as a means of introlucing some notions of science.

Here, again, many excellent looks and manuale are available, and the opportunities for laboratory illustration may he easily supplied. In fart, a most valuable line of experimentation may be followed with the scantiest of materials and expipment, such as a farmer might often possess. The skillerl and cuthusiativ teacher is able in this way to make agrieultme not only a means of gromeral culture. but a most raluahle means of approath to the more alsetraet seicinces.

9. Igriculture and Enlurged Educationul Opportunity. - 1 $\mathrm{few}$ schools have sone farther still. They have, by individual or joint effort, calried ont rertain prodnctive enterprises on land in their posession. They have engagul in sardening. and in some instanecs have performerl experiments with eertain forms of live stowk. The work has been made the center of correlat tion. for manual training, commereial arithmetic and seienee. The social significance of co-operative effort has be en revealed, and a new spirit with referenee to comntry life evolicul.

This work. while not confesserlly industrial, does sorve a raluable rocational purpose, in that it gives something of the

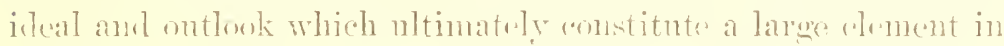
rocational sucess. But the contributions to liberal ertucation of the schnols in which this form of work has been developer are ummistakable. The wituning horizon of the pupil, his sreater srmpathy with the prosic ocenpations of life, and his growing appreciation of the possililities of art and science applied in every-day callings, tend at erery step to render him a person of power and to add to his poswililities of growtly.

There are edncators who believe that sneh a reorganization of the program of liberal education, as here deseribet. whereby special studies and practices shall lead into larger locil, industrial and social artivities, constitntes the ereatest onportunity 
of the future tor our selumels. Invienlture, as the orempation of lualf the Amerioan population and an inportant portion of the people of Massarhnsetts, is an especially inviting fiele?.

10. Motives of Liberal Educution now Dominant. - The aliove trpes of acrieultural education are all comtrolled by the motives dominant in lilenal alncation. It is not intended that they thall he dotemined ly the comblitions and monsities of vocational exlucation. It is desimble that, when the ends of

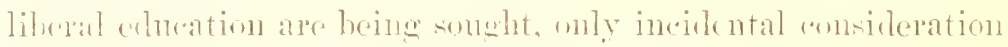
should be given to the industrial significance of the means emmorerl. Nevertheless, it must be apparent that all the above necthels of instruction, even when hased solely on the textlumk, have sune influence on rocational skill.

Sucerse in me's alling depemb on something num than skill, and raparity to apuly science and art to promluotive ends; it involves social omtlowk, wirler srmpathies and the ideals which aretuate life. While the alore forms of alneation rammot be wallen rorational, they merertheless should contribute ideals am aplemeistion, - important elements in the success of those rouths who nltinately turn to agrienlture as an ocempation.

The stmly of acrienlture above lescribed shoulel, fo far as State eneonragenent and support are concelned, stand in the sane position as the stucly of foreign langmaes, history, mathematios, scisure and all sulijects fratitionally associated with

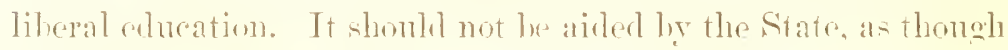
it wore part of a syotem of romational exluation. 
XI.

AGRICLLTRE AS A PHASE OF LIBERAL EDLCATION IN THE ELEMENTARY SCIIOOLS OF MISSACHUSETTS. ${ }^{1}$

$$
\text { Pirt I. }
$$

\section{The Present Status.}

While there is as yet no srstematic or general recognition of agriculture in the program of the clementary pullic schools of the State, enough has heen dome in tearhing this sulject to show that, within the limits of the capacity of the children. such instruction is entirely practicable, and that the results justify an extension of this kind of work. Eren in one-room rural schools, as at Hinstale and Pern, teachers guider and dinerted by capable and skillful supervision have orercome apparent limitations, and have given hors ranging from twelve to fourtem rears of age a knowledge of the hest methods and actual practice in the raising of cortain staple regetables. An example of one of the projects that has been found most foasible and satisfactory is given as Part II. of this chanter.

\section{Some Definite Results.}

The instruction in acriculture in the elementary schools Inas led to a general use of tho leatlets and bulletins issued hy the Tnited States Department of Agriculture. hy the State Board of Agrienlture and by the Massachusetts Agrienlturat College. Not nnly do the hows in comnection with their school projects rearl with interest and appreciation these bulletins. but the school heromes a melinm through which such information on the best methods of anlture is brought into the community itself. Fammers have thus become acquainted with approved methods of cultivating certain crops, and nse such information in their own practice. One community, for example, has learued the value of the formalin treatment for scab in potatoes, the best and cheapest combinations for ferti- 
lizers, and the nse of the Bordeanx mixture for the prevention of potato blight.

Pesides these economie results, an increased interest in and appreciation of the school have heen developed anong the people. It has been possible to introduce in such rural schools other practical projects in dressmaking and cooking, in which mdertakings the girls of the upper grammar grades have shown efficieney and ability. In these and other ways helpful relations have been established between the schow. and the arts of the farm and home. In the schools where such exercises have been introllueed with suceess. it has bren fornd that the boys acquire adiled interest in school work along all lines. The direct nse made of pemmanship, arithmetic, composition, hookkeping, drawing and manual training has resulter in an improved quality of work in those branches.

\section{The Tulue of Elementary Igriculture.}

Instruction in elementary agriculture in the upper srammar grades has a direct value in itself. becanse it eontributes to the prosperity of the farning community by aisling in the introduction of improved methods.

Teachers, by means of such courses, have heen able to increace the interest among their pupils in the work and the activities of the fam. One may hope that, throngh such influenees, hoy may be indured to remain in the comtry districts; but sufficient data are not as yet at hand to demonstrate that elementary agriculture in the sehools aceomplishes such a result. It will be agreed that it is highly desirable to make use of all pusible means to chock the present excessive tendency toward the city.

The work in agriculture in a rural school opens up a way for helpful co-operation letween the school on the one hand, and the home and the farm on the other. One of the hest opportunitios for applying the teaching of the schonl is when a boy scenres a plot of land in the home garden or farm, and enltivates it according to the hest methorls. Such an midertaling shonld he carrich ont as a husiness enterprise, an account kept of rereipte and expenditures, and a statement made at the close of the suasme which shall show the halanes of profit or lose. 
Courses in elementary agrienlture furnish a preparation for the direct rocational work in schools of higher grade. Pupils who have carried ont one or more garden enterprises have acquired some knowledge of elementary methods in farming, and some information regarding the regetable raised, soil, weather conditions, efferts of fertilizer, heat, light and moisture. They thins come to the more adraneed work with a large body of experience. which the serondary sehool teacher may utilize to advantage.

Agencics to Promote Elementury Agriculture.

1. Nature Study. - In the early rears of the school life of the pupil he is led to olwerve plant and animal life. and gains a considerable body of experience relating to the phenomena of weather, soils and local natural history. When elementary instruction in agrienlture has been thoroughly established and srstematized, it will be possible to direct and slape nature sudy so as to give it more definite aims and purposes than at present, and at the same time to retain the quality in that sturly which makes for appreciation aurl enjorment of nature.

2. School Gardens. - The school garden is wimning a place in the public schools of the State. Through the mdertakings in rolved in gardening, the pupil gains experience, knowledge and skill in certain processes comnected with farming. It is desirable that the school-garden work shonld be so directerl as to give the pupil a definite task, in acomplishing which he must orercome real difficulties in the soil, learn to protect his erep against insect pests and against untoward weather conditions, and finally secure a tangible and measurable product. The schom garden may thus closely approximate artnal farming conditions. The normal schools of the State. particulary at Torth Adans and Hramnis, are giving serions attention to school sardening of this character. T'se is being made in this atrivity of the motives that molerlie social and enllective action. while opporturity is afforded for wholesome liralry and for desire for individual exollence.

3. Potrto and Corn Chubs. - I'nder the anspices of the Massachusetts d gricultural College, a large number of bors in different parts of the State have heen organized into sociuties for 
raising mrain staples in accordance with the best scientific methods. Tnder the leadership and direction of menbers of the farculty of the Massachusetts Agrionltural college, a widespread interest in agrienture has heen developed. Seed of approver quality is distributed to the members of these clubs, and full direction- are given regarding rulture and harrecting. Exhilits are held at the close of the stason moler the anspices of local granges or other organizations. Prizes are awarded for the best results. Ber these means the bors are stimulaterl, by emulation and friendly rivalyy, to put both skill and indinstry into their individual umeretakings. Some notable result have been seened through this movement, in the culture

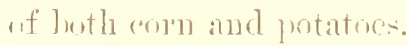

t. Summer Courses. - The Massachenetts Agrienltural College, liv its smmmer comrses for the training of teachers. by its conferences on rural conditions and by the travelling school of instruction, in which use is made of the train and trolley serrice of the State, is doing ralnalsh. work in stimulating an interest in farning and in spreading a knowldge of scientifie methorl anmong teachers.

․ The ITorti of the Board of Eduention. - In agent of the Poard of Ealueation is giving a large part of his time and attention to the encomagement and direetion of teachers and superintenclents in the establishment and conduct of elementary work in agriculture. T'nder his direction a manual is being prepared which gives directions for carrying ont a number of projects in anviculture. This publication furnishes detailed and specific instructions, whereby smerintendents and tearhers will be enaliber to emblnet classes in the different projects intelligertly and effectively. In Part II. of this chapter a brief lescriptim wit this mannal, and an example of one of the projeets are givel1.

\section{Prorisions for Extension and Development.}

In order that elementary agriculture in the grammar gradea may be arrienl an with sucess, it is necessary that teachers

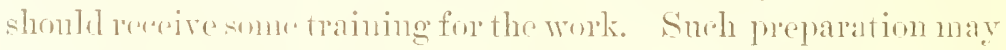
he given in sereal wars. The mannal to which reference las

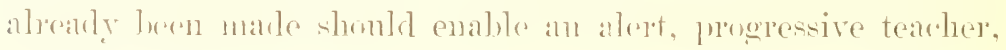


when guided hy her superintendent, to carry out with success certain undertakings in agriculture. The normal schools and the summer school at the Massachusetts Agricultural College are already rendering service by training their students for the work which falls to a teacher in a rural school, and are in some instances giving direct instruction in the proresses of farming. It is important that superintendents who are in charge of schools in the country should iniform themselves on elementary agriculture. Guidance and help from the superintendent arc important factor's in promoting the efliciency of a teacher in this field of instruction. It has been suggested that the Board of Education might well consider the question of securing a grant of money from which payments might be made to the smaller towns in order that the salaries of teachers who are making a sucess of the rork in agriculture and in other practical branches might be increased. Such an incentive would encourage capable young women to enter the service of the rural schools, and to continue in this field of work for a time. It has been shown by experience that such teacher's with a eapacity for leadership, not only improve the quality of the school work, but also exercise a most helpful influence upon the community life, this influence being shown in the better'ment of eronomic and social conditions.

\section{PART II.}

\section{Introduction.}

In agent of the Board of Education is preparing a manual for the instruction of teachers in the work of elementary agriculture. This bulletin is entitled "Some Agricultural Projects for Elementary Schools." The nature of the work is best shown by a brief description of each of the fonr parts, and by an example of one of the projects.

\section{The Divisions of the Mamual.}

Part I. The Projects. - This portion of the bulletin gives full and specific directions, whereby the children in the clementary schools, under the direction of teachers, may successfully raise such regetables as potatoes, tomatues, parsuips, lettuce. 
alfalfa and radishes. In all, fonrteen sueh undertakings are described.

Part II. Suggestions for Garden Wrork. - One finds here full directions as to how the work in gardening can be conducted to best advantage in an elementary sehool. The place of such work in the program is described, and a statement is added of the necessary equipment in land, tools, measures, seeds, fertilizers and reference and study books.

Part III. Laboratory Work. - This section contains deailed descriptions of twelve experiments relating to plants and soil.

Purt Il. Collateral Work. - Instruction is given as to the ways in which pupils may be given practies in the writing of letters, in the keeping of diaries, in applying arithmetic, drawing and manual training and in the use of busines forms in comnection with the work of elementary agriculture. Suggestions are made on the usc of material, afforderl hy elementary agriculture, as a hasis for componition exercios. Possible correlation with the work in gengraplyy and in rience is also indicated.

The manual on agrieulture projects should do much in pro. moting the practical work in the upper grammar grades, becanse it puts at the command of teachers and suprintendents a body of exercises that have been carefully prepared for use under nsual school conditions.

\section{First Project. - Potato.}

$\Lambda$ brief summary of this project is given as an illustration of the method of treatment need in the manual.

Preparation of the Soil. - Advice is given on the kinds of soil adapted for potato culture. The proper time for plowing and the methols to be nenl in preparing the soil, by harrowing and furwwing, are also discused. Several kinds of fertilizers are described. The manual points out ways wherely fertilizers may be obtained at smallest expense and applierl in the field to l,est advantage.

Seed, Selection and Preparution. - The standard varicties of seed and the qualities desired in potatoes used for planting 
are described. Other topics are: the use of the formalin solntion to prevent scab, the need of care in sprouting, and the best ways of planting.

Cultivation. - Inder this head instruction is given on hoeing and hilling. The use of Paris green to destroy the potato bug and spraying with the Bordeaux mixture to prevent blight are treated.

Harresting. - The manual tells the learner when and how a crop is harvested. A plan for estimating the number of potatoes yielderl by the field and a form for a report on the number of potatoes in cach hill are given. A list of books realing with potate culture is presented. 


\title{
APPENDIX.
}

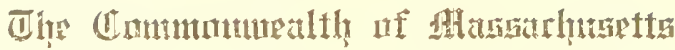

In the Jear One Thonsand Nine Hundred and Eleren.

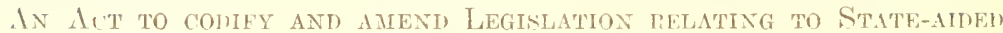 \\ Tocational Edcration.
}

Be it enacted, ete., as follows:

GONSTHUTIION.

1 SEcron 1. The fulluwine works and pluases as leveinafter used 2 in this act shall. muless a different meaning is plainly recrired by : the rontext. lave the following meanings: - -

\pm 1. "Vocational education" slall mean any education whose con$\therefore$ trolling pmone is to fit for profitable employment.

li 2. "Industrial educition " shall mean that form uf rocational edu7 calion which fits for the trades, crafts and mannfacturing pursuits, $S$ incluting the ormutions of girls and women anried on in work9 shops.

10 3. "Asricultural erlucation" shall mean that form of rocational 11 education which fits for the ecompations comnected with the tillage 12 of the soil, the eare of domestic animals, forestry and other wage13 earning or productive work on the farm.

14 4. "Honsehold arts" education shall mean that form of voca15 tional eflucation which fits for ommpations comerter with the 16 homseholi.

17 5. "Indejendent indnstrial. agriviltural or honseholit arts selool" 19 shall mean an organization of courses, pupils and tenehers. muler a 19 distinctive management approved by the board of ertueation, de20 sigued to give either industrial, agrimultural or homsehold arts edu21 cation as herein ilefined.

22 6. "Evening elass" in an industrial, agerientural or honsehold arts 2:? sthool shall mean a class giving such training as ean be taken by 24 persons alleady employed during the working day, and which, in 2.5 order to be called rocational, must in its insturtion deal with the 26 snbject matter uf the day employment, and be so carried on as 2- to relate to the day em in loyment.

"s 7. "Part-time (or entinuation) class" in an industrial, agricul2!) tural or household arts school shall mean a rocational class for prer30 sons giving a portion of their working time to profitable employment, 31 and receiving in the part-time sehool, instrution complementary to 32 the practical work which is being carried on in such employment. 
33 To give "a portion of their working time" such persons must give $3 t$ a portion of each day, week or longer period to such prart-time class 35 during the period in whieh it is in session.

36 S. "Iudependent agricultural school" shall mean either an organi37 zation of eourses, pupils and teachers, under a ilistinctive manageis ment designed to give agrieultural edueation, as hereinafter pro39 vided for, or a separate agricultural department, offering in a high 40 schocil. as elective work, training in the principles and practice of 41 agrienture of an extent and character approred by the board of 12 edueation as rocational.

439 . "Independent household arts school" shall mean a vocational 44 sehool designed to develop on a vocational basis the eapacity for 45 household work, such as the eallings of cookery, household service 46 and other oreupations in the household.

STATE ADIINISTRATION AND SLPERVISION.

1 Section 2. The board of edueation shall be pinarged with the duty 2 and given all necessary power to investigate and to aid in the intro3 duction of industrial, agricultural and household arts edueation; to 4 initiate and superintend the establishment and maintenanee of 5 schools for the aforesaid forms of edueation; and to supervise and 6 approve such sehools, as hereinafter provided. The board of edu7 cation shall make a report annually to the legislature, describing 8 the condition and progress of industrial, agrieultural and household 9 arts education during the year, and making sueh recommendations 10 as sueh board may deem advisable.

\section{TYPES OF SCHOOLS.}

1 Sector 3. In order that instruetion in the prineiples and the 2 practice of the arts may go on together, independent industrial. 3 agricultural and household arts schools may offer instruction in day, 4 part-time and evening elasses. Attendance upon such day or part5 time elasses shall be restricted to those orer fourteen and under 6 twenty-five years of age; and upon sueh evening elasses, to those 7 orer serenteen years of age.

\section{LOCAL ADIINISTRATION AND CONTROL.}

1 SECTION 4. Any eity or town may, through its sehool committee 2 or through a board of trustees eleeted by the eity or town to serve 3 for a period of not to exceed fire years, to be known as the local 4 board of trustees for vocational education, estahlish and maintain 5 independent industrial. agricultural and household arts schools.

1 Section 5. 1. Districts composed of cities or town. or cities and 2 towns. may, through a board of trustees to be known as the distriet 
3 board of trustees for rorational education, establish and maintain 4 independent industrial, agriwultural or household arts schools. Such

5 district board of trustees may consist of the chaiman and two other 6 members of the schonl committee of each of such rities and towns, 7 to be appointed for the purpose by each of the respective school comS mittees thereof: or any such rity or town may elect three resi9 dents therenf to serve as its remesentatives mu such district board 10 of trustees.

11 2. Such a district board of trustees for rocational education may 12 adopt for a perior of one year or more a plan of organization, 13 administration and surport for such selools. Such a plan, if ap14 proved by the board of erhorion, shall enatitute a binding contract 15 between the rities or towns which are, throngh the action of their 16 respective representatives on surh a ristrict board of trustees, made 17 parties thereto, and shall not be altered or amulled exrent by vote 15 of two-thirds of the entire distriet board of trustees and the consent $1 ?$ of the board of erheation to such alteration or amulment.

1 Sectron 6. Taral and district boards of trustees for vocational 3 education. administering approved industrial. agricultural or honse: hold ants sehools, shall, mudre a selieme to be alpuroved by the board 4 of elucation. appoint an alvisory eommittee composen of menhers 5 representing local trades, industries and oceupations. It slall be the fi duty of such advisory commilfees to eomsel with and advise such 7 local or district boards of trustees and other school officials having

8 the management am supervision of such schools.

\section{NON-RESIDENT PUPILS.}

1 Sermion 7. 1. Any resident of any city or town in Maswaehusetts "2 which loes not maintain an appover independent industrial, agri-

:3 rultural or household arts sehool, offering the type of training whieh t he lesires, may make applieatinn for armission to such a sehool .) maintained by another eity or town. The bratr of education. whose 6 recision slall be funal, may approve or disapprove such amplication. 7 In making such a derision the boald of education sluall take into S ermsideration: the opportunities for free vorational training in the 9 community in which the alplieant lesides; the finaneial status of 10 the rommunity: the age, sex, preparation, antiture and previous 11. reeord of the applieant; and all other relerant circumstanees.

12 2. The city or town in which the child resides, whose amplication 1.8 for admissinn to an approved independent industrial, agrieultural 14 or bousehold arts sclion maintained by another city or town has been 1.5 approved, shall pay snch tuition fee as may be fixed by the board 16 of education; and the commonwealth shall reimburse such a eity or 17 town, as provided for in this act. If any eity or tomn neglects or 


\section{3}

18 refuses to pay for such tuition, it shall be liable therefor in an action 19 of contract to the city or town, or cities and towns, maintaining the 20 school which the pupil, with the approval of the said board, 21 attended.

\section{REIMLURSEMENT.}

1 Section 8. Independent industrial, agricultural and household 2 arts sehools shall, as long as they are approved by the board of 3 education as to organization, control, location, equipment, courses 4 of study, qualifications of teachers, methods of insiruction, conditions 5 of admission, employment of pupils and expenditures of money, 6 constitute approved local or district independent vocational schools.

7 Cities and towns maintaining such approved local or district inde$S$ pendent vocational schools shall receive reimbursement as provided 9 for in sections nine and ten of this act.

1 Section 9. 1. The commonwealth, in order to aid in the mainte2 nance of approved local or district independent industrial and house3 hold arts schools and of independent agricultural schools consisting 4 of other than agricultural departments in high schools, shall, as pro5 vided for in this act, pay anmully from the treasury to cities and 6 towns maintaining such schools an amount equal to one-half the sum 7 to be known as the net maintenance sum. Such net maintenance sum $S$ shall consist of the total sum raised by local taxation and expended 9 for the maintenance of such a school, less the amount, for the same 10 period, of tuition claims, paid or mpaid, and reecipts from the work 11 of pupils or the sale of products.

12 2. Cities and towns maintaining approved local or district inde1:) pendent agricultural schools consisting only of agricultural depart14 ments in high schools shall be reimbursed by the commonwealth, as 1.) provided for in this act, only to the extent of two-thirds of the 16 salary paid to the instructors in such agricultural departments: pro17 vided, that the total amount of money expended by the common18 wealth in the reimbursement of such cities and towns for the salaries 19 of such instructors for any given year shall not exceer ten thousand 20 dollars.

213 . Cities and towns that have paid claims for tuition in approved 2.) local or district independent vocational schuols sliall be reimbursed $2: 3$ by the commonwealth, as n'orided for in this act, to the extent of 24 one-half the sum expended by such cities and towns in payment of 25 such claims.

1 SECTION 10. On or before the first Wednestay of Jamuary of each 2 year the board of edncation shall present to the legislature a state3 ment of the amount expended previous to the preceding first day 4 of December by eities and towns in the maintenance of approved 
5 local or district independent vocational schools, or in payment of 6 claims for tuition in such schools, for which such cities and towns 7 should receive reimbursement, as provided for in this act. On the $S$ basis of such a statement the legislature may make an appropriation (y) for the rembursement of snch cities and towns uy to such first day 10 of December.

ACTS AND PARTS OF ACTS REPEALED. .

1 Segtion 11. 1. Sections one to six inclusive of chapter five hum2 dred and five of the acts of ninetcen lundred and six, sections one to 3 fonr inclusive of chapter five hundred and seventy-two of the acts of 4 nineteen hundred and eight, chapter five hundred and forty of the

5 acts of nineteen hnndred and nime, and all acts and parts of acts 6 inconsistent herewith, are bereby repealed.

7 2. Schools, heretofore established under the acts and parts of acts s repealed loy this section, and approved by the board of education, 9) shall continue in operation subject to the provisions of this act for 10 such sehools. 


\section{THE COMMONWEALTH OF MASSACHUSETTS}

\section{REPORT OF THE BOARD OF EDUCATION ON AGRI- CULTURAL EDUCATION}

Submitted to the Legislature of Massachusetts of 1911, in accordance with Chapters 108 and 133, Resolves of 1910 






\section{LIBRARY OF CONGRESS}

||||||||||||||||||||||||||||||||||||||||||||||||

口00ट78 29405 